\title{
Deposits, character and timing of recent eruptions and gravitational collapses in Tatun Volcanic Group, Northern Taiwan: Hazard-related issues
}

\author{
Alexander Belousov ${ }^{\mathrm{a}, \mathrm{b}, *}$, Marina Belousova ${ }^{\mathrm{a}, \mathrm{b}, \mathrm{c}}$, Chang-Hwa Chen ${ }^{\mathrm{a}}$, Georg F. Zellmer ${ }^{\mathrm{a}, \mathrm{d}}$ \\ a Institute of Earth Sciences, Academia Sinica, 128 Academia Road Sec. 2, Nankang, Taipei 11529, Taiwan \\ b Earth Observatory of Singapore, Nanyang Technological University, N2-01a-15, 50 Nanyang Avenue, 639798 Singapore \\ c Institute of Volcanology and Seismology, Petropavlovsk, Russia \\ ${ }^{d}$ Lamont-Doherty Earth Observatory, 61 Route 9W, Palisades, NY10964, USA
}

\section{A R T I C L E I N F O}

\section{Article history:}

Received 28 July 2009

Accepted 1 February 2010

Available online 12 February 2010

\section{Keywords:}

extrusive eruption

explosive eruption

pyroclastic

edifice collapse

volcanic hazard

Taiwan

\begin{abstract}
A B S T R A C T
Taipei City, with a population of around 8 million, as well as two nuclear power plants is located in close proximity to the Quaternary, dominantly andesitic Tatun Volcanic Group (TVG) of Northern Taiwan. We have investigated the stratigraphy of the youngest volcaniclastic deposits, as well as the morphology of lava flows and domes of the TVG in order to reconstruct the character and timing of the most recent eruptions and related hazardous events in the area.

Our data indicate that recent eruptions of the group were dominated by long-term, voluminous extrusions of crystal-rich, very viscous lavas. These eruptions formed closely spaced monogenetic domes and lava flows. Based on morphological parameters of the lava flows (thicknesses $80-150 \mathrm{~m}$, lengths up to $5.6 \mathrm{~km}$, and volumes up to $0.6 \mathrm{~km}^{3}$ ), average rates of magma effusion ranged from 1 to $10 \mathrm{~m}^{3} / \mathrm{s}$, eruption durations from 500 to 1800 days, and lava front speeds from 0.5 to $6 \mathrm{~m} / \mathrm{h}$.

Explosive activity of TVG was diverse, ranging from weak phreatic to highly explosive (VEI 4) Plinian eruptions; vulcanian activity with deposition of lithic ashes was most common. Interaction of rising magma with ground water frequently occurred during the eruptions.

This study presents the first radiocarbon dates of various volcaniclastic deposits of the TVG, which indicate that Cising, Siaoguanyin, and possibly Huangzuei volcanoes had magmatic eruptions in the period 13,00023,000 years ago. In addition, Mt. Cising had a phreatic eruption 6000 years ago, and possibly an effusive eruption just before that. Gravitational collapses of volcanic edifices with volumes $0.01-0.1 \mathrm{~km}^{3}$ and $H / L$ $0.16-0.25$ were also common. They occurred on intersections with tectonic faults and may have been triggered by seismic activity. The youngest collapses occurred at Mt. Siaoguanyin (23,000 BP) and Mt. Cising (6000 BP).

It is concluded that the TVG should be considered volcanically active. The results of this study provide a basis for volcanic hazard assessment and mitigation in the area.
\end{abstract}

(c) 2010 Elsevier B.V. All rights reserved.

\section{Introduction}

The Tatun Volcanic Group (TVG) of Northern Taiwan is located in close proximity to one of the most densely populated areas of the world, with 7,800,000 inhabitants living in Taipei City and its suburbs (GeoNames geographical database). The region has a well-developed modern industrial infrastructure, as well as two nuclear power plants built directly near the foot of the volcanoes. The TVG itself includes the popular Yangmingshan National Park, which is visited by thousands of people every day. The consequences of a volcanic eruption of any type

\footnotetext{
* Corresponding author. Current address: Earth Observatory of Singapore, Nanyang Technological University, N2-01a-15, 50 Nanyang Avenue, 639798 Singapore. Tel.: +65 6291334876.

E-mail address: abelousov@ntu.edu.sg (A. Belousov).
}

and scale would therefore be devastating for the region, and damage of the nuclear power plants may have a global impact.

The potential for renewed activity of the TVG has been debated for some time (Song et al., 2000a; Konstantinou et al., 2007). Although the group has not had any historical eruptions, its volcanic edifices are well-preserved and are dotted by multiple hot springs and solfataras with temperatures up to $116^{\circ} \mathrm{C}$ (Witt et al., 2008). Detailed investigations undertaken in recent years have provided several lines of evidence that an active magma chamber is present below the TVG: (1) compositions of gases from the TVG fumaroles indicate their origin from a magmatic source (Yang et al., 1999; Lee et al., 2005; Lee et al., 2008; Witt et al., 2008); (2) shallow-level seismicity similar to seismicity under active volcanoes has recently been observed (Lin et al., 2005; Kim et al., 2005; Konstantinou et al., 2007); and (3) geodetic measurements (leveling and GPS) reveal steady local ground deformations of the TVG, which may be caused by pressure 
changes at depth, possibly associated with migration of magma and/or hydrothermal fluids (Yu et al., 1997; Konstantinou et al., 2007).

To estimate the probability of future eruptions of the TVG, to predict their character, as well as to estimate eruption-related hazards, the history of volcanism of the area needs to be understood. Investigations of the geology of the group started in the beginning of the 20th century (Oshima, 1907; Deguchi, 1912) and continue to the present day due to the geothermal potential of the area (Chen, 1970, 1975; Yen et al., 1984; Ho, 1986; Chen, 2000). The first studies of the physical volcanology of the group were undertaken by Chen and Wu (1971), and Wang and Chen (1990). Song et al. (2000a) provided a brief description of pyroclastic deposits and suggested a general scheme for the geological history of the group. More recently, the first volcanic hazard assessment for the TVG was provided (Kim et al., 2005).

Here, we present the results of detailed investigations of the physical volcanology of the youngest TVG volcanoes. Special attention was given to the stratigraphy of various volcaniclastic deposits (tephras, lahars, and debris avalanches). In addition, morphologies of lava flows and domes were studied. Our goals were: (1) to date the most recent eruptions; (2) to reconstruct their scales and mechanisms; and (3) to estimate probability of different types of eruptions of the TVG in the future.

\section{Geographical and geological backgrounds of TVG}

The Quaternary TVG occupies $400 \mathrm{~km}^{2}$ in the north of Taiwan Island. The tectonic position of the group is extremely complex (Fig. 1). In this region, two volcanic island arcs, Ryukyu and Luzon, merge (South China Sea and Philippine Sea plates are subducting in almost opposite directions) and simultaneously collide with the Eurasian continent (Kim et al., 2005; Hsu et al., 2009). However, the northern part of the Luzon arc has already been subducted (and partly obducted) under Eurasia and does not play a role in the recent volcanism of the TVG. In addition, ongoing rapid subduction (at approximately $8 \mathrm{~cm} /$ year) of the Philippine Sea plate under the Ryukyu arc is highly oblique in the western part of the arc, and therefore may arguably not be the principle cause of volcanism in the area. Moreover, while the Wadati-Benioff zone of the Ryukyu arc plunges at an angle close to $45^{\circ}$ under northern Taiwan, the continuation of the zone currently cannot be detected directly below the TVG, which is located slightly off the lateral edge of the subducting plate. Thus, although geochemically the magmas of the TVG bear a clear subduction signature, some researchers have attributed its origin to the opening (gradual westward "unzipping") of the Okinawa Trough, which represents the Back Arc Basin of the Ryukyu arc (Teng, 1996). Others consider the origin of the TVG to be related to extension associated with the collapse of the Taiwan orogen (Wang et al., 1999, 2004).

The TVG is built on an angular unconformity with sedimentary basement composed mostly of Miocene quartz sandstones of shallow marine origin (Chen, 2000). Xenoliths of these sandstones are abundant in products of the TVG (Chen, 1965; Fuh, 1968). The basement is moderately folded and dissected by many faults, including several major thrust faults striking NE. Along the margins of the TVG, the basement rocks can be found as high as several

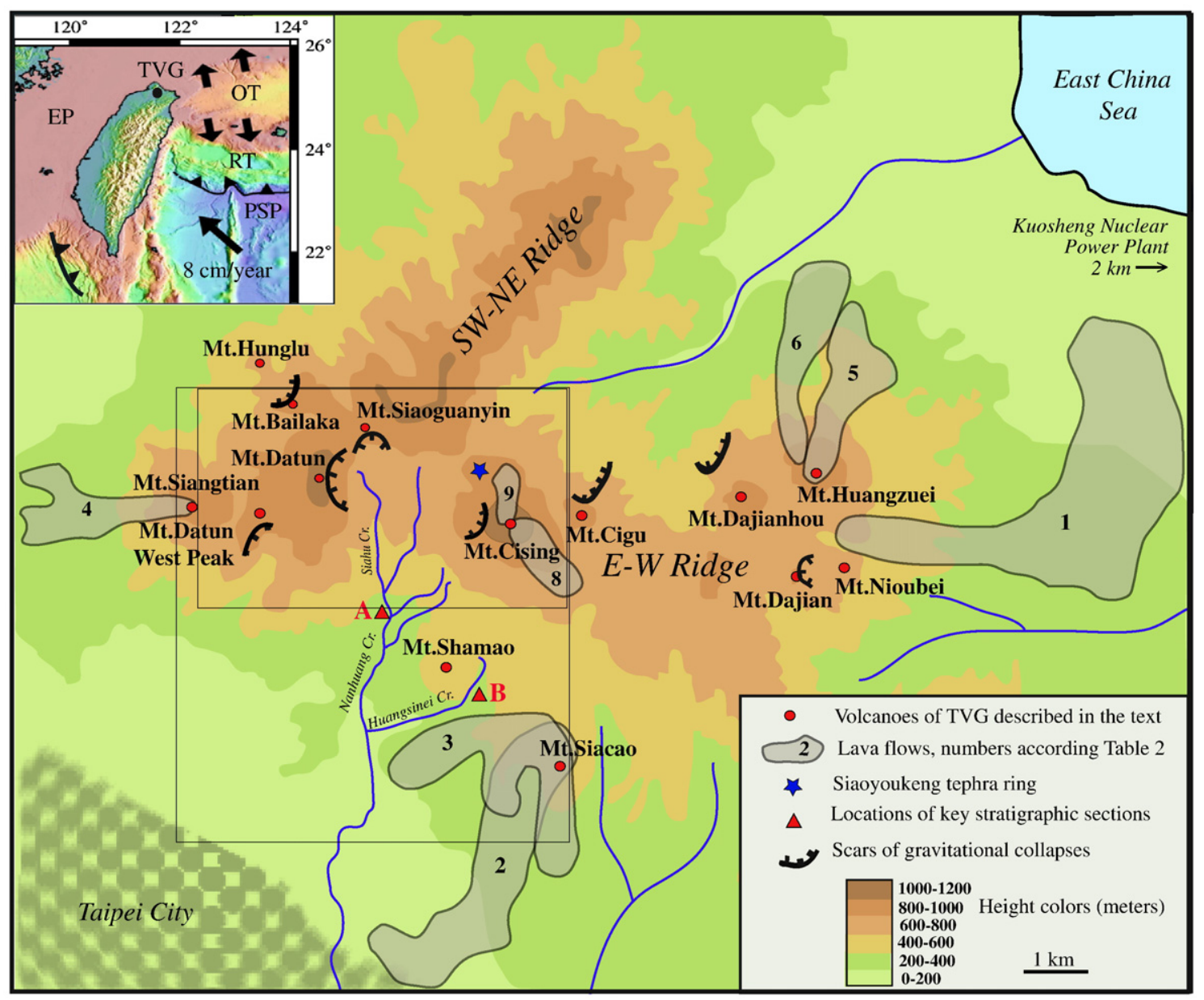

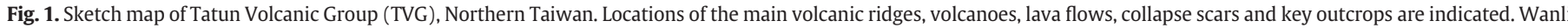

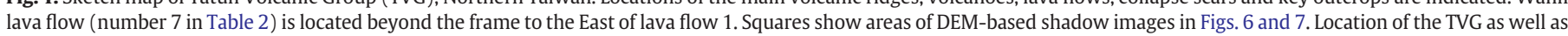
the tectonic regime of Taiwan is shown in the inset. EP-Eurasian Plate, PSP -Philippine Sea Plate, OT-Okinawa Trough, RT -Ryukyu Trench. 
hundred meters asl, but drilling has shown that the base of volcanic rocks in the center of the group lies at about $1000 \mathrm{mbsl}$ (MRSO, 1969). Song et al. (2000b) suggested that this may be due to the existence of a hypothetical "cauldron" in that area - formed by gradual subsidence of the roof of a magma chamber, while magma was extruded along circular faults, resulting in the observed volcanism.

The TVG consists of two principal volcanic ridges (Fig. 1): an E-W ridge, obliquely $\left(\sim 45^{\circ}\right)$ intersected at its western end by a SW-NE ridge. Each ridge is approximately $15 \mathrm{~km}$ long, and has an average elevation in the range of 800-1000 masl. On topographic maps and digital elevation models (e.g. Chen et al., 2003) of the area it is clearly visible that the SW-NE ridge has a sharp ridge crest and very steep alpine slopes shaped by intensive water erosion. In contrast, ridge crests and slopes of the E-W ridge are notably gentler and retain many primary volcanic landforms: cones, craters, and lava flows with lateral levees and pressure ridges (Yang et al., 2004; Liu et al., 2007). Since both ridges are located in similar climatic conditions, and are composed of rocks having similar mechanical properties, these observations indicate that the $\mathrm{E}-\mathrm{W}$ ridge is much younger than the SW-NE ridge: consequently, we have focused our investigations on the volcanoes of the $\mathrm{E}-\mathrm{W}$ ridge.

The $\mathrm{E}-\mathrm{W}$ ridge axis is not well defined: although many of the volcanoes are located close to the ridge crest, some volcanoes are situated up to $3 \mathrm{~km}$ away from it. Linear rows of volcanoes, which would indicate their formation along the same eruptive fissure, are not observed. The ridge is composed of approximately 20 major wellpreserved volcanic edifices, the highest of which is Mt. Cising at 1120 masl $^{1}$ (Fig. 1, Table 1).

Most of the individual volcanic edifices are rather steep-sided (slopes up to $40^{\circ}$ ) and of small-to-moderate size, with relative heights of $100-400 \mathrm{~m}$, base diameters of $0.5-2 \mathrm{~km}$, and volumes of $0.05-$ $0.3 \mathrm{~km}^{3}$. Detailed DEM-based topographic profiles across several of the edifices can be found in Chen et al. (2003) and Liu et al. (2007). The volcanic edifices are closely spaced and their bases frequently overlap. Despite their small sizes, absolute heights of the cones commonly reach $800-1000$ masl, because they are superimposed on the older volcanic foundation.

Throughout its geological history, the TVG produced dominantly andesites. While the SW-NE ridge is composed almost exclusively of two-pyroxene andesites without hornblende, the $\mathrm{E}-\mathrm{W}$ ridge consists of andesites bearing high percentages of hornblende (Wang and Chen, 1990; Chen, 2000). This indicates a significant change in water content of magma and potentially the plumbing system of volcanoes associated with the shift of volcanism from the SW-NE ridge to the E-W ridge. Only one small cone (Mt. Hunglu), located in W part of the E-W ridge, was found to be composed of basalts.

Extensive dating of the TVG rocks using fission track, $\mathrm{K}-\mathrm{Ar}$ and $\mathrm{Ar}-\mathrm{Ar}$ methods was undertaken by various authors (Juang and Chen, 1989; Tsao, 1994; Chen et al., 2003). Wang and Chen (1990) and Song et al. (2000a) determined that there were two major pulses of volcanism in the area: at about 2.8-2.5 Ma and 0.8-0.2 Ma. Cising, Dajianhou, and Huangzuei were identified as the youngest volcanoes of the TVG, with ages in the range of 0.3-0.2 Ma, and possibly Mt. Hunglu is as young as $0.11 \mathrm{Ma}$. For the deeply eroded volcanoes of the SW-NE ridge, published ages of several hundreds of thousands of years seem plausible. However, for the youngest volcanoes of the E-W ridge such ages appear to be

\footnotetext{
${ }^{1}$ Transliterations of topographic names from Chinese language into English, which are used on different maps of the area, commonly have disparate spellings. For example, Mt. Cising is also referred to as Mt. Qixing. In this paper, we follow the Tongyong Pinyin transliteration, which is used on the latest tourist map of Yangmingshan National Park. In order to minimize possible misunderstanding, transliterations of the most important geographic names of the TVG can be found in the Table 1. Although in the chosen transliteration the spelling "Datun" is used to designate the name of the main mountain, the spelling "Tatun" is used in this paper to designate the name of the whole volcanic group because the name "Tatun Volcanic Group" has been widely used in many previous papers.
}

Table 1

Transliteration of main topographic names from Chinese into English.

\begin{tabular}{|c|c|}
\hline English & Chinese \\
\hline Mt. Bailaka & 百拉卡山 \\
\hline Mt. Cigu & 七股山 \\
\hline Mt. Cising & 七星山 \\
\hline Mt. Dajian & 大尖山 \\
\hline Mt. Dajianhou & 大尖後山 \\
\hline Mt. Datun & 大屯山 \\
\hline Mt. Datun, West Peak & 大屯山西峰 \\
\hline Mt. Huangzuei & 誉嘴山 \\
\hline Mt. Hunglu & 烘繬山 \\
\hline Mt. Miantian & 面天山 \\
\hline Mt. Nioubei & 牛背山 \\
\hline Mt. Shamao & 紗帽山 \\
\hline Mt. Siangtian & 向天山 \\
\hline Mt. Siaocao & 小草山 \\
\hline Mt. Siaoguanyin & 小觀音山 \\
\hline Mt. Siaoyoukeng recreation area & 小油坑遊稳區 \\
\hline Kuosheng lava flow & 國興岩流 \\
\hline Nanhu lava flow & 南湖岩流 \\
\hline Siaocao lava flow & 小草山岩流 \\
\hline Waishuangsi lava flow & 外雙溪岩流 \\
\hline Wanli lava flow & 萬里岩流 \\
\hline Huangsinei Creek & 磺溪內溪 \\
\hline Siahu Creek & 下湖溪 \\
\hline
\end{tabular}

inconsistent with the excellent preservation of their primary volcanic landforms.

Prior to our study, the timing of the youngest eruptions of the TVG remained open. The group has not had any historical eruptions, but the historical period for Taiwan formally started in the Qing Dynasty, only about 300 years BP. Before our investigations, no radiocarbon dating of volcanic deposits within the TVG had been undertaken. However, several layers of volcanic ash were found in drill cores from the nearby Taipei Basin. These yielded ${ }^{14} \mathrm{C}$ ages of less than $20 \mathrm{ka}$ separated in time by about 3000 years (Chen and Lin, 2000, 2002; Song et al., 2007), and were shown to be geochemically similar to the products of the TVG. Thus, while the last period of voluminous volcanism within the TVG was initially thought to have taken place several hundred thousand years ago, there was a possibility that some eruptions had occurred much later, and potentially during the Holocene.

\section{Extrusive volcanism of TVG}

Yen et al. (1984) was the first to notice that products of extrusive volcanism in the TVG strongly prevailed over those of explosive volcanism. We have investigated the morphology of well-preserved lava domes and flows in order to determine eruptive parameters of the most recent extrusive eruptions. Details of the petrology of TVG lavas are given in Chen (1975), Lo (1982) and Wang et al. (2004).

\subsection{Lava domes}

Examination of available outcrops has shown that the vast majority of well-preserved volcanic cones of the E-W ridge are composed of massive, poorly-to-moderately vesiculated crystal-rich andesitic lava with no internal layering. This fact, together with the dome-like steep-sloped morphology of the edifices, indicates that the dominant style of recent volcanism of the TVG was extrusion of viscous lava. Some domes (Shamao, Miantian, and Dajian) have very steep slopes, reaching $50^{\circ}$ in their upper parts (Fig. 2a). These domes were formed by extrusion of almost completely solidified magma (plug domes or Pelean-type domes). Less steep slopes of some other domes (Datun, Dajianhou, and Huangzuei) indicate that they were formed by extrusion of less viscous lava, which was still able to deform plastically. Most edifices are close to half-spherical with one summit, indicating formation during single episodes of continuous magma extrusion. Thus, most domes may be considered monogenetic. 
a

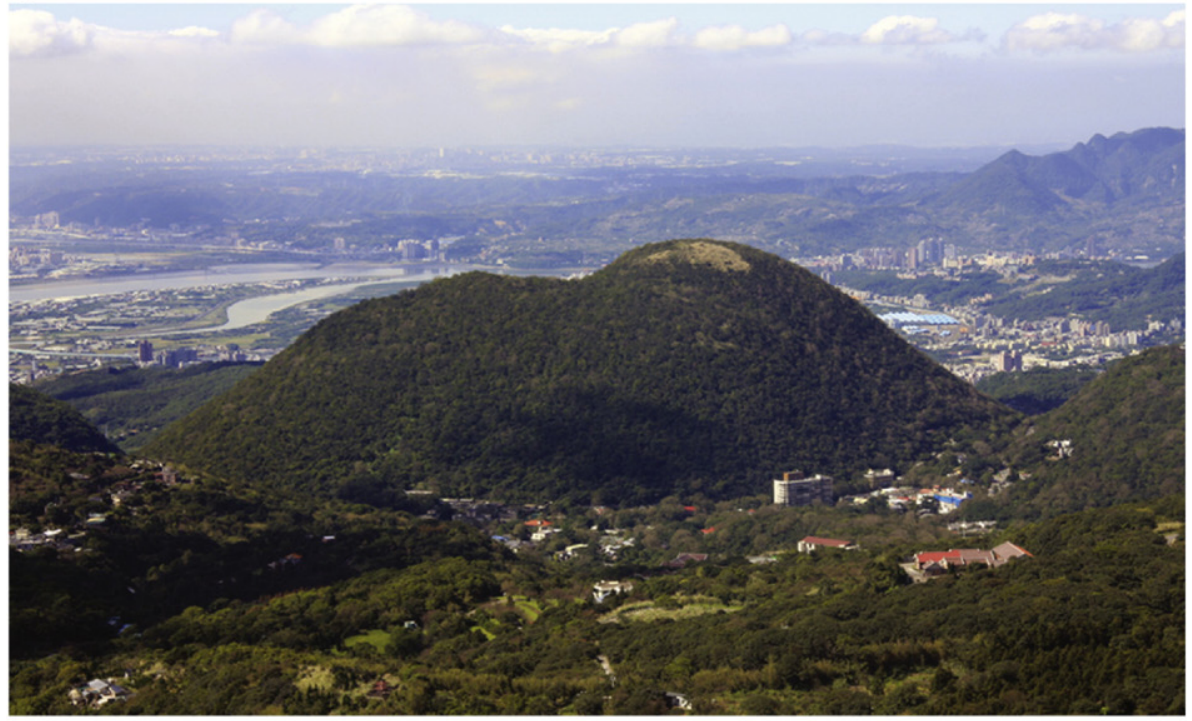

b

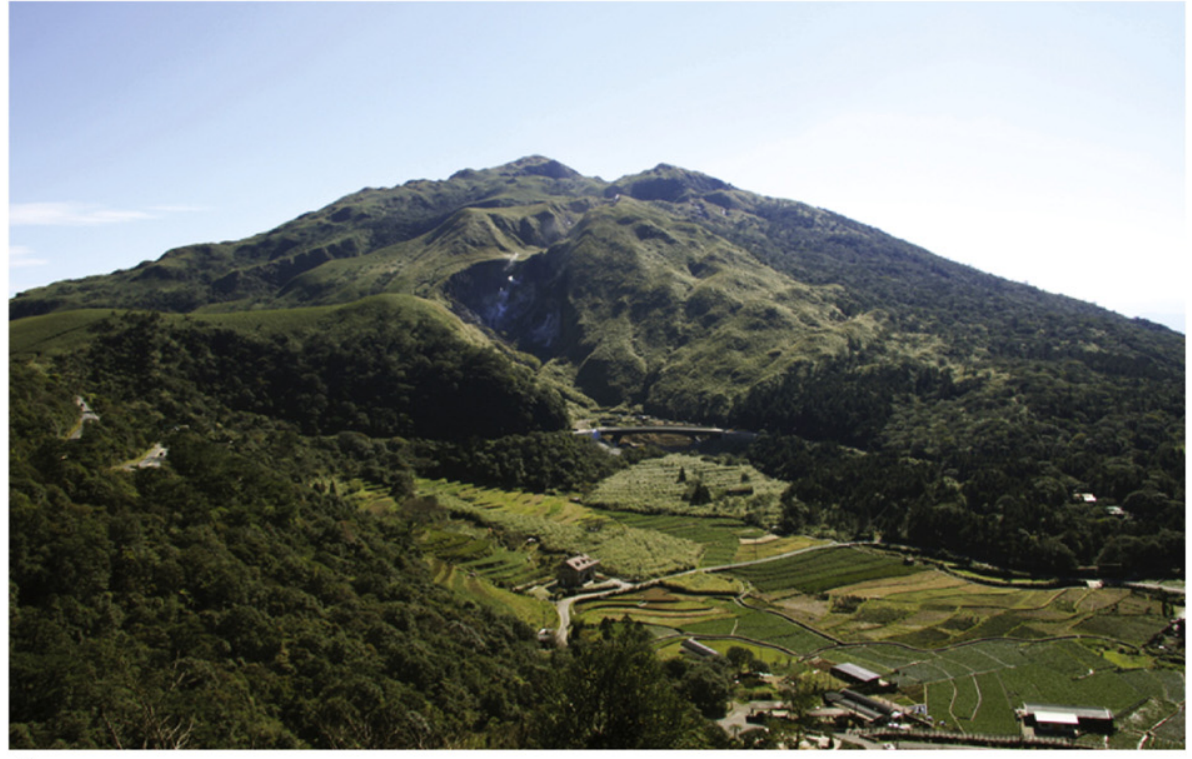

c

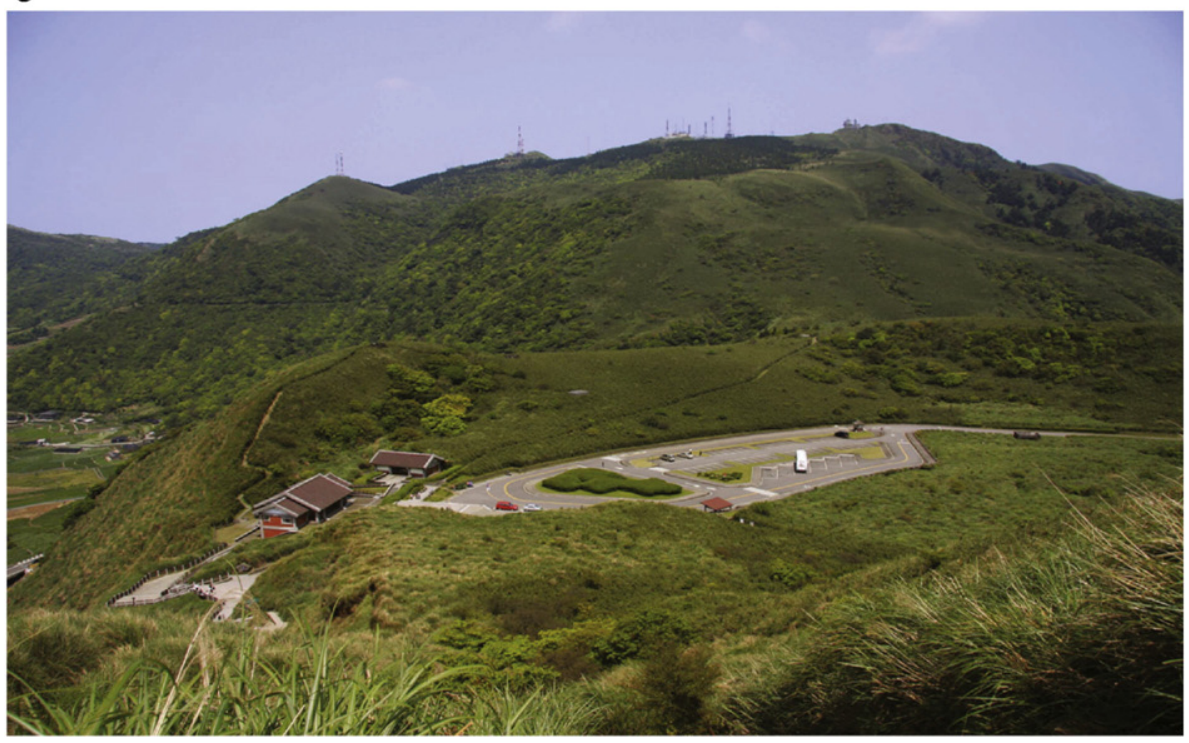


Available outcrops show that the domes are surrounded by short, steep-sided aprons of very coarse, clast-supported gravel deposits. The constituent rock clasts are of the same lithology as the domes; many have radial cooling joints and are oxidized to various degrees, indicating high temperatures during their deposition. These are smallvolume deposits of hot avalanches accompanying dome extrusion. Few deposits of block-and-ash flows were found, and explosive episodes as well as Merapi-type dome collapses therefore had small volumes and were probably rare.

Based on observations of historical dome-forming eruptions (e.g., Walker, 1973; Zharinov and Demyanchuk, 2008; Vallance et al., 2008) as well as on physical modeling of dome-building eruptions (Fink and Griffiths, 1998), many studies have shown that volcanic domes form when the average discharge rate of the magma is low; commonly $<1 \mathrm{~m}^{3} / \mathrm{s}$. This implies that each of the dome-forming eruptions of the TVG lasted several years to decades, in order to form edifices with volumes of $0.05-0.3 \mathrm{~km}^{3}$. However, structures of some domes of the TVG (Cising, Huangzuei, Siangtian) are more complicated, with deviating thick lava flows, indicating that the discharge rate of lava fluctuated during the course of some dome-forming eruptions, periodically exceeding $1 \mathrm{~m}^{3} / \mathrm{s}$.

Several domes (e.g. Huangzuei and Siangtian) have well- or partially-preserved crater-like depressions on their summits. No pyroclastic deposits were found on the crater rims, suggesting that these craters are not likely to be of explosive origin. Instead, they may have formed by subsidence as a result of magma receding back into the conduit (due to flank outbreak of lava, intrusion of magma at depth, or collapse of bubbles in the conduit through late-stage degassing).

Notably, the edifice of Cising volcano (Fig. 2b), which is the largest in the TVG, is different from the other domes: it was formed by several extrusive episodes, separated by periods of repose and/or periods of explosive activity. The structure of Mt. Cising is composed of lava domes and thick lava flows. Thus, Cising volcano can be classified as a polygenetic effusive lava dome, being structurally transitional to a stratovolcano. The youngest lava flows of Mt. Cising will be described in the next section.

\subsection{Lava flows}

In the TVG, there are nine well-preserved lava flows (Figs. 1 and $2 b)$. The flows have clearly defined outer boundaries allowing easy tracing from their frontal parts to their source. Most of the flows start at the slopes and summit areas of lava domes. Thicknesses of the flows are great (80-150 m), and the frontal parts are very steep, indicating high magmatic viscosities and yield strengths. Most flows consist of only one long branch (so-called single flows). Nanhu and Siacao flows have several branches. DEM and topographic maps show that many flows have various large-scale surface structures common for viscous lava flows: longitudinal lateral levees and transverse pressure ridges (Yang et al., 2004). Structures typical for blocky andesitic lava flows are observed. Upper surfaces of the flows are composed of up to $15 \mathrm{~m}$ thick autobreccia - large vesicular lava blocks (meters across) surrounded by sandy gravel of the same composition. Contacts of brecciated and non-brecciated lava are sharp, but very irregular. The upper parts of lava flows are often vesicular (average 30\%), while internal parts are dense (5-10\%) and massive or display platy joints.

It was first shown by Walker (1973) that lengths of a lava flows depend mostly on magma discharge rate. Later, several methods to determine eruptive parameters based on the geometry of lava flows were devised (e.g. Moore et al., 1978; Kilburn and Lopez, 1991; Lyman et al., 1994; Stevenson et al., 1994; MacKay et al., 1998; Lyman et al., 2004). We have determined geometrical parameters of the TVG lava flows from a 1:50,000 topographic map of the area, and have calculated the parameters of their eruptions (Table 2). The data show that effusive eruptions at TVG occurred with average magma discharge rates up to $10 \mathrm{~m}^{3} / \mathrm{s}$ and lasted up to several years, producing lava flows with lengths up to $5.6 \mathrm{~km}$ and volumes up to $0.6 \mathrm{~km}^{3}$.

The edifice of Hunglu volcano is exceptional among TVG edifices, because a significant part of it is composed of multiple, relatively thin (of the order of a few meters) "aa" type lava flows of basaltic composition.

\section{Explosive volcanism of the TVG}

Few primary pyroclastic deposits are preserved in TVG. Even if it is assumed that a significant part of pyroclastic units was removed by erosion, volumes of magma erupted in the form of pyroclasts constitute less than a few percent of the total volume of magma erupted in the TVG. Thus, eruptions of the TVG were less explosive than eruptions of subduction-related volcanoes in general.

Pyroclastic products of TVG are dominated by tephra fall units with rare block-and-ash pyroclastic flow and surge deposits. No ignimbrites (welded or unwelded) were found. Among the fallout deposits of the TVG we have distinguished: (1) pumice fallout deposits of plinian eruptions; (2) lithic ashfall deposits of vulcanian eruptions; and (3) explosive breccias of wet phreatomagmatic and phreatic eruptions.

\subsection{Deposits of pumice fallout of Plinian eruptions}

With rare exceptions, all deposits of this type were found on the slopes of Cising volcano. A significant part of the deposits was remobilized by lahars soon after deposition (see Section 6). The characteristics of both pumice and lithics in the Plinian deposits differ significantly from one outcrop to another, thus several (at least 4) different eruptions, which likely originated from different vents, occurred at Mt. Cising. A vent of only one of these eruptions has been discovered. We refer it as Siaoyoukeng tephra ring because it is located near Siaoyoukeng recreational area (Figs. 1 and 2c). This is the only volcanic edifice of the TVG that is completely composed of pyroclastic material. The vents of the other Plinian eruptions may have been located somewhere in the summit area of Mt. Cising and are now completely buried by the youngest lava flows of this volcano.

Deposit of the Siaoyoukeng tephra ring. Only about $1 / 4$ of the area of the tephra ring is exposed: its eastern part is buried/destroyed by deposition of the Cising 2 lava flow, and its southern part is buried by the Cising debris avalanche. The preserved part allows an estimate of the dimensions of the ring: crater rim diameter $-300 \mathrm{~m}$, base diameter $-500 \mathrm{~m}$, and maximum relative height $-40 \mathrm{~m}$. Outer slopes of the ring edifice have inclinations of around $20^{\circ}$.

The ring is composed of unconsolidated well-sorted, clastsupported coarse lapilli (Fig. 3). The material is represented by strongly vesicular pumice (vesicularity $49-66 \%$, average $59 \%$ ) evenly intermixed with a large percentage (up to $40 \%$ ) of lithics. The pumice is grey andesite, with thin alternating bands of darker, moderately vesicular, and lighter (almost white) highly vesicular material. Lithics are represented by uniform, nonvesicular, grey andesite, as well as by a very small percentage of other rock types. Close to the base the

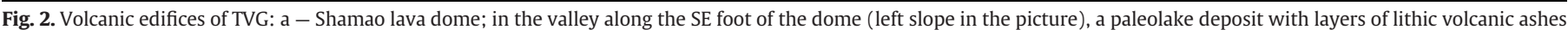

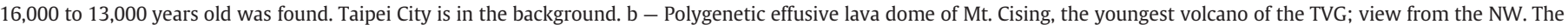

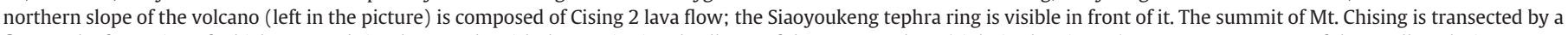

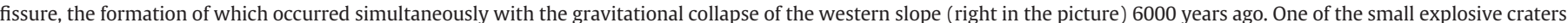

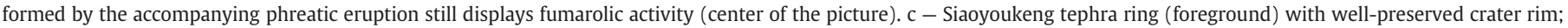

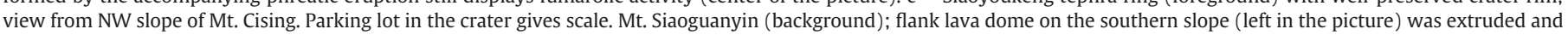
then experienced gravitational collapse $\sim 23,000$ years ago. 
Table 2

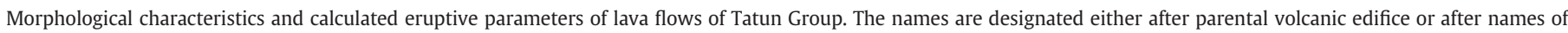
nearest geographical features. Numbers of the lava flows according Fig. 1. For flows having branches (numbers 3 and 4 ) the sum length of the branches is indicated.

\begin{tabular}{|c|c|c|c|c|c|c|c|c|c|c|}
\hline Name of lava flow & Kuosheng & Waishuangsi & Siacao & Nanhu & Huangzuei 1 & Huangzuei 2 & Wanli & Cising 1 & Cising 2 & Method \\
\hline Number & 1 & 2 & 3 & 4 & 5 & 6 & 7 & 8 & 9 & From topographic \\
\hline Length, m & 5600 & 5000 & $\begin{array}{l}3 \text { branches } \\
7500\end{array}$ & $\begin{array}{l}3 \text { branches } \\
3400\end{array}$ & 3600 & 3700 & 2500 & 2000 & 1000 & map $1: 50,000$ \\
\hline Width, m & 950 & 900 & 680 & 660 & 720 & 500 & 400 & 700 & 700 & \\
\hline Thickness, m & 80 & 100 & 120 & 80 & 150 & 80 & 150 & 150 & 100 & \\
\hline $\begin{array}{c}\text { Slope angle, } \\
\text { degrees }\end{array}$ & 4.5 & 8.5 & 6 & 9 & 11 & 9.5 & 7.5 & 14 & 14.5 & \\
\hline Volume, $\mathrm{m}^{3}$ & $4.3 \times 10^{8}$ & $4.5 \times 10^{8}$ & $6 \times 10^{8}$ & $1.8 \times 10^{8}$ & $4 \times 10^{8}$ & $2 \times 10^{8}$ & $1.5 \times 10^{8}$ & $2 \times 10^{8}$ & $7 \times 10^{7}$ & \\
\hline Density, $\mathrm{kg} / \mathrm{m}^{3}$ & 2500 & 2650 & 2420 & 2560 & 2570 & 2600 & 1900 & 1900 & 1900 & $\begin{array}{l}\text { Houghton and } \\
\text { Wilson (1989) }\end{array}$ \\
\hline Yield strength, pa & $1.6-1.7 \times 10^{5}$ & $3-4 \times 10^{5}$ & $3.2-5 \times 10^{5}$ & $2.5-3.3 \times 10^{5}$ & $7.4-8.1 \times 10^{5}$ & $3.2 \times 10^{5}$ & $0.4-1.0 \times 10^{6}$ & $6-6.5 \times 10^{5}$ & $2.7-5 \times 10^{5}$ & $\begin{array}{l}\text { Moore et al. } \\
\text { (1978) }\end{array}$ \\
\hline Effusion rate, $\mathrm{m}^{3} / \mathrm{s}$ & 10 & 6.8 & 6.4 & 4.2 & 2.6 & 3.5 & 1 & 1.4 & 1 & $\begin{array}{l}\text { Lyman et al. } \\
(2004)\end{array}$ \\
\hline Viscosity, Pa.s & $6.2-6.8 \times 10^{9}$ & $3-4 \times 10^{10}$ & $1.4-2.4 \times 10^{10}$ & $1.6-2.2 \times 10^{10}$ & $2.3-2.5 \times 10^{11}$ & $1.2 \times 10^{10}$ & $0.4-1.3 \times 10^{11}$ & $5-5.5 \times 10^{10}$ & $1.3-2.5 \times 10^{10}$ & $\begin{array}{l}\text { Stevenson et al. } \\
\text { (1994) }\end{array}$ \\
\hline $\begin{array}{l}\text { Mean front } \\
\text { velocity, } \mathrm{m} / \mathrm{h}\end{array}$ & $2.3-2.5$ & $1.1-1.4$ & $2.0-3.2$ & $1.6-2.2$ & 0.5 & 2.6 & $1.7-5.8$ & $2.3-2.5$ & $2.2-4.5$ & $\begin{array}{l}\text { MacKay et al. } \\
(1998)\end{array}$ \\
\hline $\begin{array}{l}\text { Eruption duration, } \\
\text { days }\end{array}$ & 500 & 750 & 1100 & 500 & 1800 & 650 & 1700 & 1600 & 650 & $\begin{array}{l}\text { Lyman et al. } \\
(2004)\end{array}$ \\
\hline
\end{tabular}

deposit is especially coarse: clasts of pumice reach $10 \mathrm{~cm}$ in diameter, and lithics up to $15 \mathrm{~cm}$. The deposit contains ballistic blocks of angular dense andesite up to $50 \mathrm{~cm}$ in diameter, which likely represent underlying rocks ripped off from the conduit walls.

Outside the tephra ring, fallout deposit of the same eruption with a thickness of about $40 \mathrm{~cm}$ was found at a distance $1.3 \mathrm{~km}$ from the source, where it is represented by coarse lapilli with clasts of pumice up to $8 \mathrm{~cm}$ in diameter.

SEM images of the pumice show that it has round bubbles tens to hundreds of microns across, separated by thin $1-10 \mu \mathrm{m}$ walls of glass (Fig. 4a,b). Bubbles frequently coalesced, forming larger irregular vesicles (up to a few $\mathrm{mm}$ across). The character of broken bubble walls indicates that the magma was ductile during fragmentation.

Vesicularity indices of the pumice as well as grain-size characteristics of the tephra are similar to those of deposits of dry Plinian eruptions (Walker, 1981; Houghton and Wilson, 1989). The erupted magma volume can roughly be estimated at $0.1-0.3 \mathrm{~km}^{3}$. Based on the grain size and volume of the deposit, we suggest that the eruption was of VEI 4 scale, with an eruption column approximately 15-20 km high (Newhall and Self, 1982; Pyle, 1989).

Deposits of other Plinian eruptions of the TVG have grain-size distributions similar to the deposit of the Siaoyoukeng tephra ring. Vesicularity indexes of pumices from these deposits are lower (vesicularity $36-56 \%$, average $48 \%$ ), and bubbles are smaller than those of the tephra ring pumice. The eruptions that ejected these relatively dense pumices may have been of phreatomagmatic type, in which case the vesiculation of magma was arrested by chilling when it came into contact with water.

Fission track dating of zircons from the Siaoyoukeng tephra ring deposit yielded an age of $0.5 \pm 0.08 \mathrm{Ma}$ (Wang and Chen, 1990). However, good preservation of the tephra ring edifice, composed of friable and easily-erodible pyroclastic material, as well as the presence of fresh glass in the pumice, suggests a much younger age. Based on stratigraphic relations with other deposits in the area, we suggest that all Plinian eruptions of Mt. Cising, including that which formed the Siaoyoukeng tephra ring, were closely spaced in time and occurred at the very end of Pleistocene (see Section 7).

\subsection{Lithic ashes of vulcanian eruptions}

Lithic ashes were found in two principle locations: (1) the area immediately to the south of the cones of Dajianhou and Huangzuei volcanoes; and (2) the area near the southern foot of Shamao lava dome.

In the Mt. Dajianhou-Huangzuei area a layer of light-brown ash of $30-40 \mathrm{~cm}$ thickness mantles the ground surface. It rests on brown clay (strongly weathered lava) and is covered only by soil layer of $20-30 \mathrm{~cm}$ thickness. The ash is medium-coarse grained, well-sorted (Fig. 3a) and has poorly developed parallel lamination. In many locations it is moderately indurated (turned into tuff). The ash particles are poorly vesiculated and have an angular, blocky morphology.

The ash layer becomes notably thicker and coarser grained towards Mt. Huangzuei, indicating that the ash may have been erupted by that volcano. Moreover, near the foot of Huangzuei numerous ballistically deposited blocks several tens of $\mathrm{cm}$ across are scattered on the surface of the ash. The blocks are composed of dense, dark-grey andesite with poorly developed "bread-crust" surfaces, and are dissected by radial cooling joints. The material of the blocks is similar to that of the ash. Multiple xenoliths of Miocene sandstones up to several cms across are enclosed in the andesite of the ballistic blocks.

Morphologies of both the ash particles and the ballistically deposited blocks indicate that they were formed as a result of fragmentation of very viscous (possibly already solid) poorly vesicular magma. The explosions were probably phreatomagmatic, and occurred during the initial and/or intermediate stages of extrusion of the Huangzuei lava dome. Relatively good sorting of the fallout ashes suggests that these were relatively dry phreatomagmatic eruptions (i.e. that the magma/water ratio was high). We refer to that explosive activity as "vulcanian" in a broad sense (Heiken and Wohletz, 1985; Morrissey and Mastin, 2000).

Based on the degree of preservation of the ash layer, as well as the thickness of soil above it, this ash may be of the very end of Pleistocene-Early Holocene age.

In the Mt. Shamao area, four ash layers (designated by numbers 1 to 4 from bottom to top) are intercalated with very fine-grained and finely laminated deposits of a paleolake (Fig. 5). This small lake was formed when a landslide from the southern flank of Shamao lava dome dammed the narrow valley of Huangsinei Creek. The lake sediments (partially chemogenic) were deposited in oxygen-poor low-energy conditions, suggesting that the lake was rather deep in addition to being partially fed by thermal springs. The lake therefore provided favorable conditions for burying and preservation of ash layers. The exposed ash layers are accordingly 5, 6, 20 and $3 \mathrm{~cm}$ thick, 

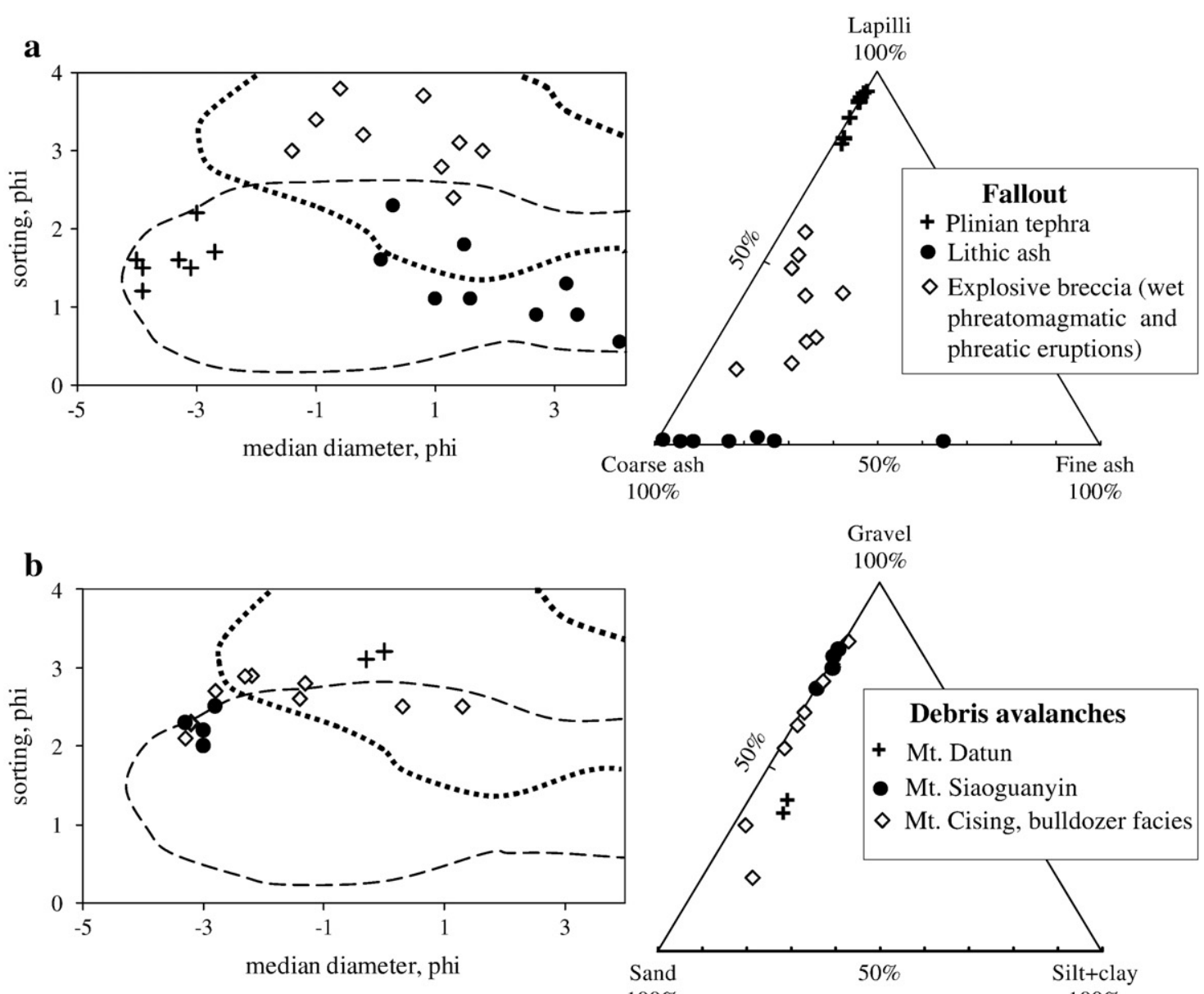

Gravel
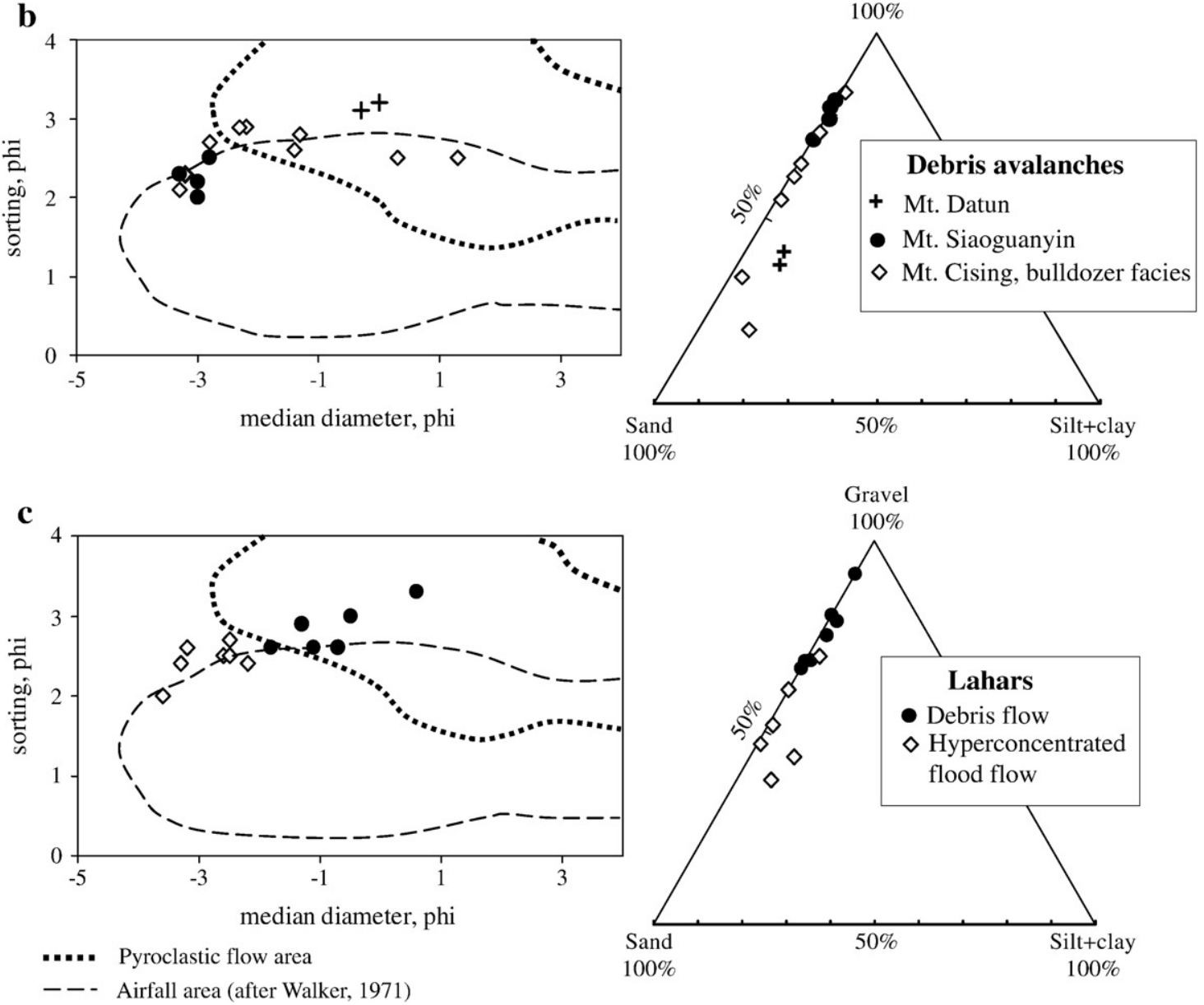

Fig. 3. Median diameter versus sorting (Inman coefficients) and ternary diagrams of grain size (silt + clay/fine ash $<0.063 \mathrm{~mm}$, sand/coarse ash $0.063-2 \mathrm{~mm}$, gravel/lapilli $>2 \mathrm{~mm}$ ) of volcaniclastic deposits of TVG: a- fallout, b-debris avalanches, c - lahars (Walker, 1971).

and have sharp contacts with the lake sediment. The uppermost layer 4 is traceable over considerable distance.

Morphology and grain-size characteristics of the ash particles (although they are notably finer grained) are similar to the ash found in the Mt. Dajianhou-Huangzuei area (Figs. 3a and 4c,d) and probably have originated from similar vulcanian-type explosions. Radiocarbon dating has shown that the ash layers were deposited in the very end of Pleistocene (see Section 7).

\subsection{Explosive breccias of wet phreatomagmatic eruptions}

A deposit of this type makes up a small well-preserved tuff cone at the summit of Hunglu volcano. The major (and older) part of the Mt. Hunglu edifice represents a shield-like volcano composed of thin lava flows of basaltic composition. The lava edifice had a crater of about $350 \mathrm{~m}$ width, which is now almost completely buried by the tuff cone. Part of the rim of the old crater is recognizable in the W-NW parts of 

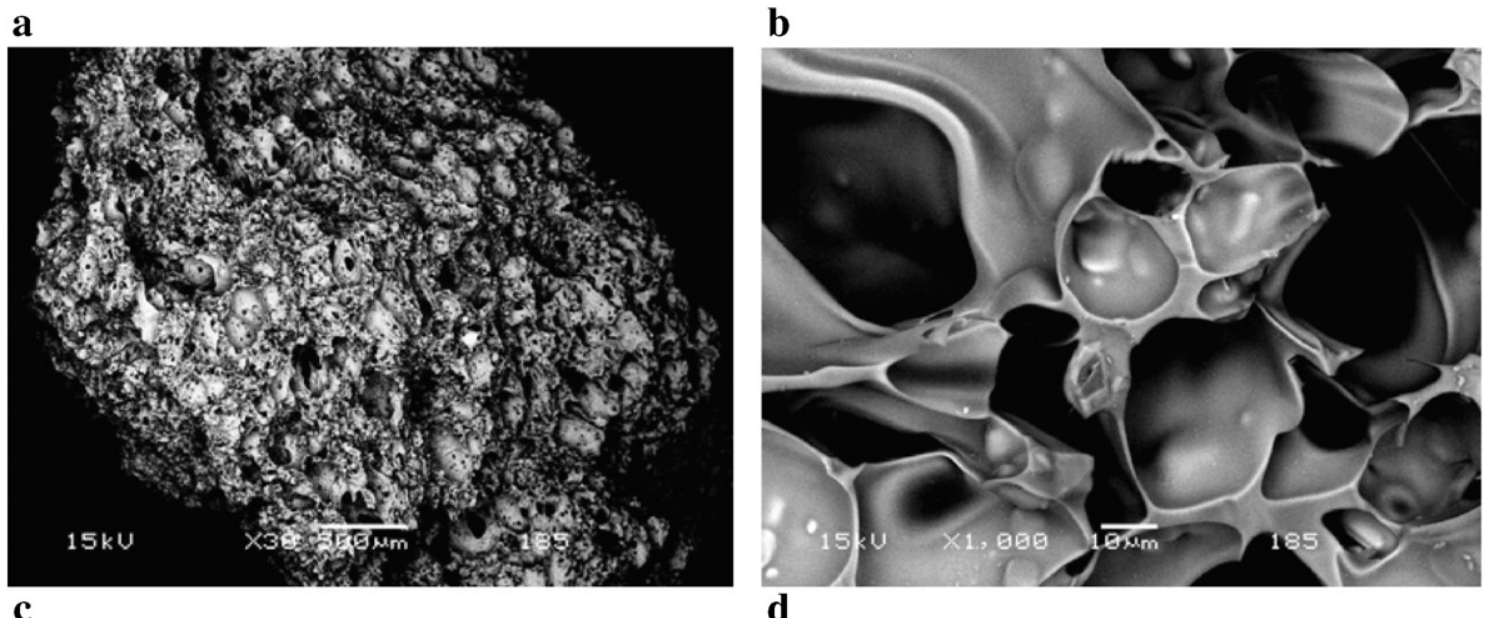

c
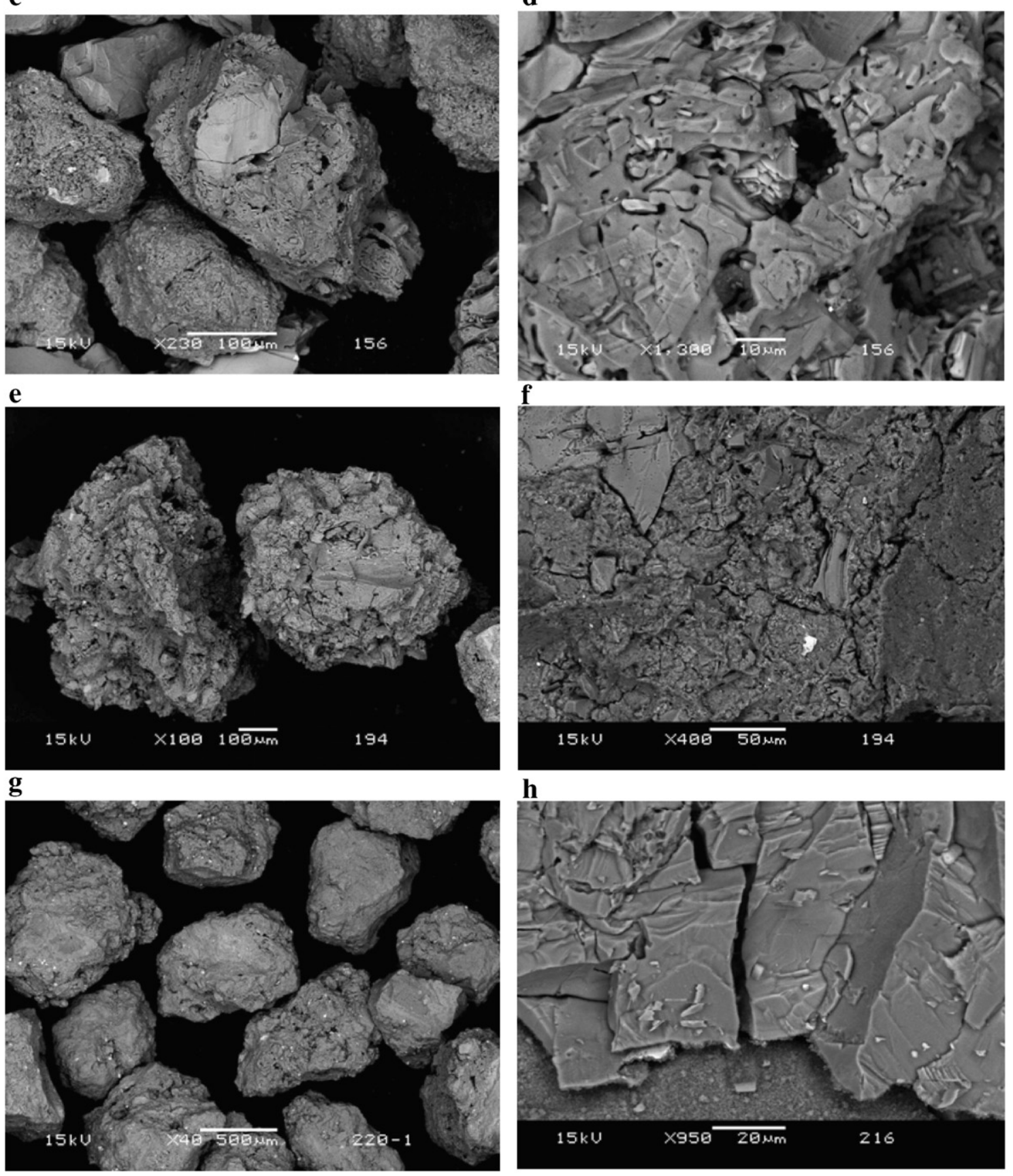
a

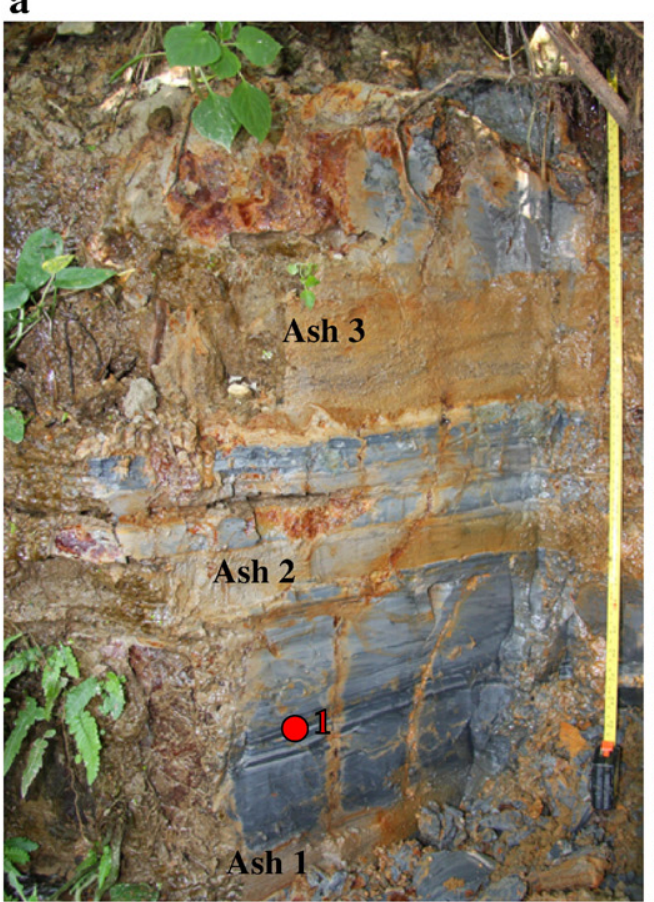

b

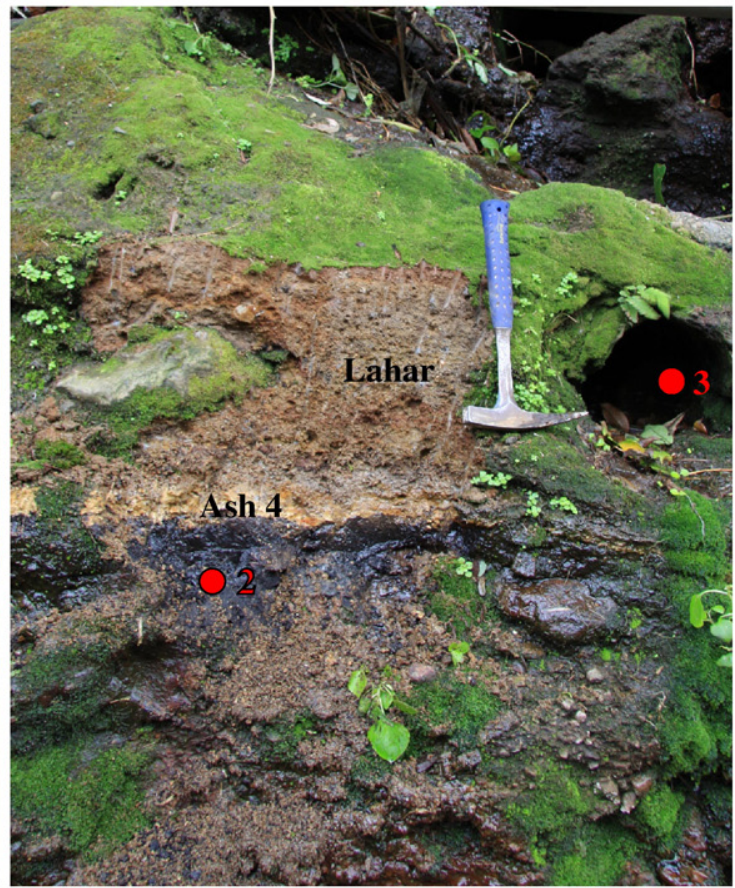

c

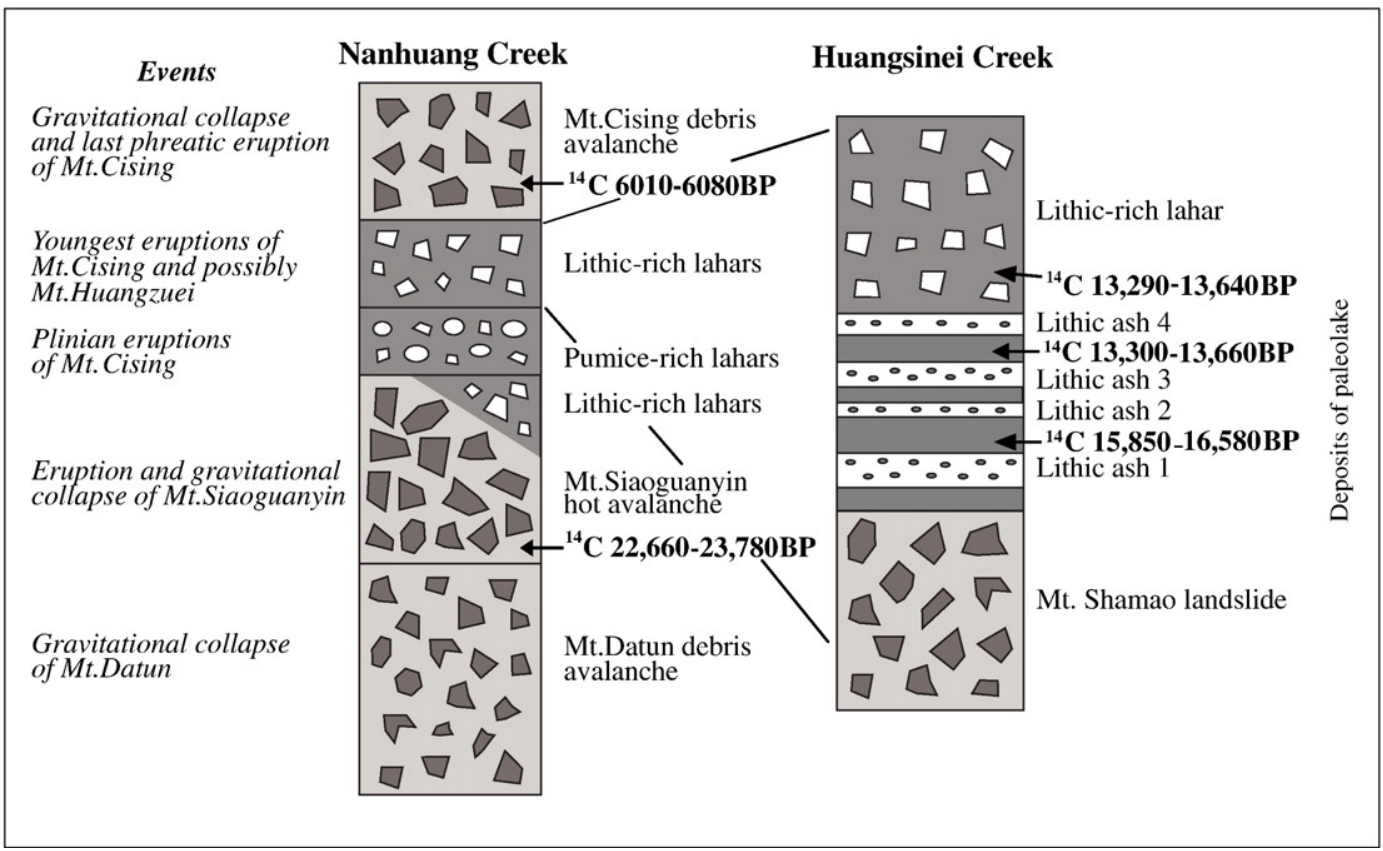

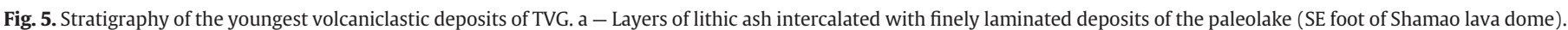

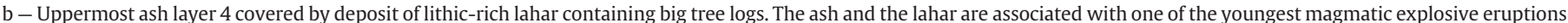

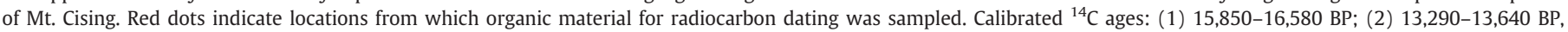

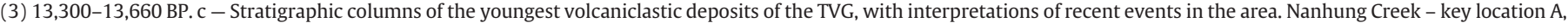
Huangsinei Creek - key location B on Fig. 1.

the summit area. The intracrater tuff cone has a base diameter of approximately $400 \mathrm{~m}$, its maximum relative height is $40 \mathrm{~m}$ and the diameter of its crater is $150 \mathrm{~m}$.
The tuff cone is composed of very poorly sorted weakly indurated breccia (massive or with crude layering parallel to the cone slope), which is composed of angular or slightly subrounded coarse lapilli in a

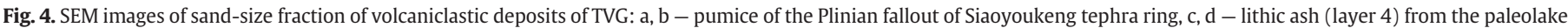

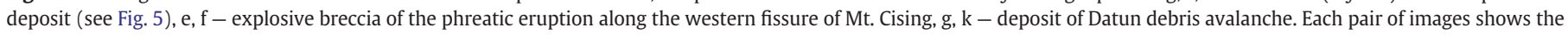
same material under different magnifications. 
coarse sandy matrix (Fig. 3a). Rock clasts are represented by poorly-tomoderately vesicular basalt (vesicularity $8-20 \%$ ). Numerous ballistically deposited blocks up to $1.5 \mathrm{~m}$ across are scattered along the crater rim of the tuff cone. The blocks are composed of dense, dark-grey basalt with poorly developed "bread-crust" surfaces, and dissected by radial cooling joints.

Very poor sorting, coarse grain size, blocky morphology of particles and low vesicularity of juvenile clasts in these deposits are similar to explosive breccias of wet phreatomagmatic eruptions (Wohletz and Sheridan, 1983; Belousov and Belousova, 2001).

The occurrence of a wet phreatomagmatic eruption from the summit of a rather high cone composed of basaltic lava flows is a rather unusual phenomenon. We speculate that before the formation of the tuff cone, the old Hunglu crater may have contained a crater lake or swamp (similar to that of the modern Hunglu crater). When basaltic magma found its way to the surface on the bottom of the old crater, water would have interacted with the magma, resulting in the wet phreatomagmatic character of this eruption.

Lava flows underlying the tuff cone yield a $\mathrm{K}-\mathrm{Ar}$ age of $0.11 \mathrm{Ma}$ (Tsao, 1994). However, based on the degree of preservation of the tuff cone, as well as on the thickness of soil above it, this deposit may be significantly younger (end of Pleistocene to early Holocene).

\subsection{Explosive breccias of phreatic eruptions}

These deposits surround several small explosive craters with diameters of up to $170 \mathrm{~m}$, located along two prominent fissures dissecting summit area of Cising volcano. The fissures are sub-parallel in $\mathrm{N}-\mathrm{S}$ orientation. The western fissure is $2000 \mathrm{~m}$ long and up to $120 \mathrm{~m}$ wide, while the eastern fissure is $1000 \mathrm{~m}$ long and up to $100 \mathrm{~m}$ wide (Liu et al., 2007). The fissures are probably of tectonic origin, but their opening caused phreatic explosions which formed the craters. Along the western fissure a large part of a lava flow of Mt. Cising detached and slid downslope in the form of a low mobility debris avalanche (see Section 5).

Aprons of the breccias around the craters are up to several meters thick and a few hundred meters wide. The deposits are massive, or display poorly developed parallel layering. They are composed of very poorly sorted angular blocks in a matrix of fine ash. In many locations the deposits are weakly indurated. Ash particles have a blocky morphology, indicating fragmentation of solid lava (Fig. 4e,f). The material represents fragments of internal parts of the lava flows of Mt. Cising (poorly-to-moderately vesicular grey andesite).

Significant amounts of hydrothermally altered rocks were not found in the breccias. Thus, the explosions that ejected these breccias were probably not of hydrothermal origin. The explosions may have occurred when fissure opening caused rapid lithostatic unloading of variously vesicular rocks of internal parts of the youngest lava flows of Mt. Cising. This may only have happened soon after deposition of the lava flows, while they were still hot and contained pressurized gas bubbles. Similar phreatic eruptions occurred at Avachinsky volcano in 2001, when a fissure crossed a lava flow deposited in 1991 (Venzke et al., 2009, and unpublished data of Belousov and Belousova).

The explosions occurred simultaneously with a gravitational collapse of Mt. Cising, which took place about 6000 BP (see Sections 5 and 7).

\section{Gravitational mass movements}

The slopes of the youngest volcanic edifices of the TVG are smooth and weakly dissected by erosion, but many of them have broadly opened (up to $140^{\circ}$ ) horseshoe-shaped depressions, $0.5-1 \mathrm{~km}$ across (Figs. 1, 6 and 7). The morphologies of these depressions are identical to scars formed by large-scale gravitational collapses. The scars are shallow-incised (100-200 m), and failure planes did not intersect the volcanic conduits. In most cases, the scars are not filled by younger volcanic edifices. Thus, there was no volcanic activity following these collapses, which probably occurred some period of time after the volcanoes had ceased to erupt. Possible exceptions are Mt. Bailaka, in the scar of which the cone of Hunglu volcano is located, and Mt. Dajian, in the scar of which Mt. Nioubei is located.

Many of the scars are situated where volcanic edifices are intersected by tectonic faults. In some cases (Mts. Datun and Cising) these are NNESSW-oriented faults clearly visible as lineaments on DEM-based shadow images of the TVG (Figs. 6 and 7). Some collapses (e.g., Mt. Siaoguanyin) may have been facilitated by EW-oriented faults, which are less prominent in the images. Some of the collapse scars (Mts. Cigu, Dajianhou, Datun West Peak) are asymmetric in plain view; one of the branches of their "horseshoe" is notably shorter than the other (Fig. 1). Their shorter branches may have formed along -E-W trending faults, while their longer branches occurred along NNE-SSW trending faults. Debris avalanche deposits connected to the formation of the horseshoeshaped collapse scars of Datun, Siaoguanyin, Cising (Fig. 6), Cigu, and Dajianhou volcanoes were investigated; their characteristics are summarized in Table 3.

The avalanches of Datun, Siaoguanyin and Cising volcanoes were confined by the deep valley of Siahu Creek, where they cover one another (Fig. 7).

The largest of the avalanches, with a volume $\sim 0.1 \mathrm{~km}^{3}$, was formed as a result of collapse of the E part of Mt. Datun which was detached by the NNE-SSW-oriented Chihshan fault. The collapsed material formed a typical debris avalanche deposit composed mainly of block facies (terminology after Glicken, 1998): meters-sized domains of strongly shattered, deformed, but not completely intermixed material of the former volcanic edifice. The dominant rock type of the avalanche consists of variously vesicular porphyritic hornblende andesite (lightgrey, grey, or reddish due to oxidation) similar to the andesites of Mt. Datun. The deposit is coarse-grained and poorly sorted (Fig. 3b); particles have blocky morphology (Fig. 4g,k) with microcracks common for debris avalanche deposits (Komorowski et al., 1991). The avalanche was moderately mobile with $H / L \sim 0.2$ (Table 3 ). The rear slide blocks of the avalanche did not travel far from the source; they stopped high inside the collapse scar, forming multiple narrow toreva blocks descending downslope.

The Siaoguanyin debris avalanche deposit is in most locations represented by uniformly massive, very coarse grained, fines-poor, gravelly material (Fig. 3b) with boulders up to several meters across. At the northern slope of Mt. Huangsi the deposit is represented by avalanche blocks (oval domains a few meters in size, composed of monolithologic, weakly fragmented dark-grey dense andesite). The blocks are surrounded by heterolithologic thoroughly intermixed material containing abundant clasts of Miocene sandstone picked up from the avalanche substrate. This is a "bulldozer facies" (terminology after Belousov et al., 1999), which was formed when the avalanche collided with the topographic obstacle.

The dominant rock type of the avalanche consists of dark-grey, dense (vesicularity 7-20\%), subaphyric andesite, similar to andesites of the southern flank dome of Mt. Siaoguanyin. Other rock types are rare in the deposit. The Siaoguanyin debris avalanche must have been hot during emplacement, because its deposit contains carbonized wood. Andesite boulders within the avalanche deposit frequently have radial cooling joints, and in rare cases "bread-crust" surfaces, giving the deposit the appearance of a lithic-rich pyroclastic flow. The paucity of fine fractions in the deposit can be connected with elutriation of fines into the convective cloud when the hot avalanche travelled down slope. Thus the deposit bears features of both debris avalanches and lithic-rich Merapi-type pyroclastic flows. The characteristics of the avalanche deposit indicate that crystallized, degassed, but still hot material of a newly extruded lava dome was involved in the collapse.

The Siaoguanyin debris avalanche was rather mobile $(H / L \sim 0.16)$, despite its small volume (Table 3 ); its speed reached $40 \mathrm{~m} / \mathrm{s}$ at a 


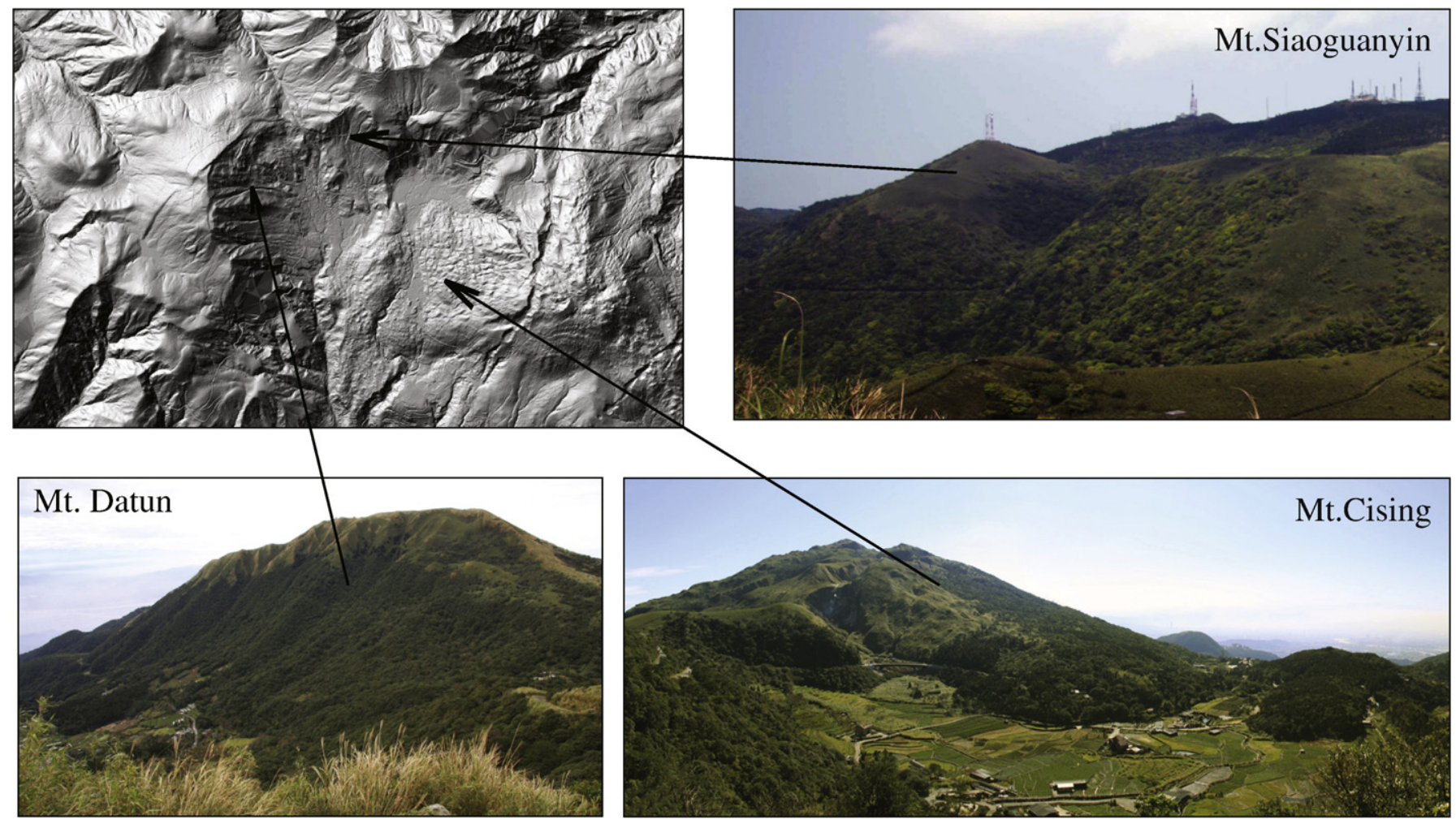

Fig. 6. Scars formed by gravitational collapses of volcanoes Datun, Siaoguanyin, and Cising, and their location on the DEM-based shadow image (cf. small square in Fig. 1)

distance of $5 \mathrm{~km}$ from the source. This calculation is based on $80 \mathrm{~m}$ high runup of the avalanche on Mt. Huangsi.

The youngest collapse with a volume of $\sim 0.05 \mathrm{~km}^{3}$ occurred at Mt Cising. The collapse took the form of numerous retrogressive landslide blocks, which only partially transformed into a debris avalanche of low mobility with $H / L \sim 0.25$ (Fig. 8; Table 3 ). The leading snout of the landslide collided with the lower eastern slopes of Mt. Datun (where the avalanche formed a bulge - Mt. Jhuzihhu with a relative height of $70 \mathrm{~m}$ ) then made a $90^{\circ}$ left turn to the valley of Siahu Creek, along which it traveled for about $1 \mathrm{~km}$. Rear sliding blocks of the collapse traveled only several hundred meters and stopped near the landslide source (Fig. 7). The former lava flow that was involved in the collapse underwent only weak disintegration: material of the collapse is represented by big angular boulders with little fine-grained matrix. The dominant rock type of the avalanche is medium-vesicular (vesicularity $10-37 \%$, average $24 \%$ ), porphyritic, light-grey hornblende andesite (sometimes slightly reddish due to oxidation).

Around the distal snout of the avalanche, as well as along its southern margin, a "bulldozer facies" is well developed (Figs. 7 and 8). The deposit is poorly sorted, coarse-grained (Fig. 3b), and lacks internal layering. It forms a band of up to $200 \mathrm{~m}$ width and $>10 \mathrm{~m}$ thickness, consisting of various types of material scraped by the avalanche from the substrate, displaced over a distance of several hundred meters, and thoroughly, although not completely, intermixed. Clasts of dense dark-grey andesite picked up from the Siaoguanyin debris avalanche deposit prevail in the facies (hence the grain-size characteristics of several samples of the facies are similar to those of the Siaoguanyin debris avalanche); reddish material of former autobreccia of lava flows dominates locally. Some pumice as well as material of lithic ashes (in the form of weakly cemented layered blocks) admixed in minor amounts. Such a diverse composition results in the broad scattering of grain-size characteristics of this deposit (Fig. 3b).

Collapses of Mt. Cigu and Dajianhou volcanoes had small volumes of $\sim 0.01 \mathrm{~km}^{3}$ (Table 3), and the character of their deposits is transitional to large rockfalls (composed of large boulders with little matrix).
The studied collapses occurred after the volcanoes had ceased to erupt, and thus were not directly associated with volcanic activity. Hydrothermally altered rocks do not make up significant parts of the studied debris avalanches, although hydrothermal fields are common in the scars of the collapses. Probably weakening of mechanical properties of the volcanic edifices due to hydrothermal alteration did not play a key role in the studied collapses, but elevated fluid pressure and hydrothermal alteration in the foundations of the volcanoes may have had some role. The collapsed parts of the volcanic edifices were detached by tectonic motions, with collapses possibly triggered by seismic activity.

\section{Lahars}

A significant proportion of the volcaniclasts of the TVG is composed of lahar deposits. Deposits of each lahar are commonly massive, poorly sorted, and have thicknesses of 2 to $10 \mathrm{~m}$.

Based on grain size and texture of the deposits, two types of lahars can be distinguished: poorer sorted debris flows (having broad polymodal grain-size distributions), and better sorted hyperconcentrated flood flows (the grain-size distributions of which have one prominent coarse mode) (Fig. 3c). Deposits of debris flows are matrixsupported: large boulders are evenly distributed in a fine-grained silty to sandy matrix; these deposits are commonly weakly cemented. Deposits of hyperconcentrated flood flows are clast-supported: large boulders are distributed in gravelly matrix; these deposits are commonly friable. Individual debris flows have produced large volume deposits, but were relatively rare. Individual hyperconcentrated flood flows have produced smaller volume deposits, but occurred more frequently.

Lithic-rich and pumice-rich varieties of lahars can be distinguished based on density/vesicularity of constituent rock fragments. In some of the pumice-rich lahars the pumice content reaches $70 \%$ by volume. Density/vesicularity distributions of pumice from the lahars (vesicularity $49-64 \%$, average $56 \%$ ) are similar to density/vesicularity 


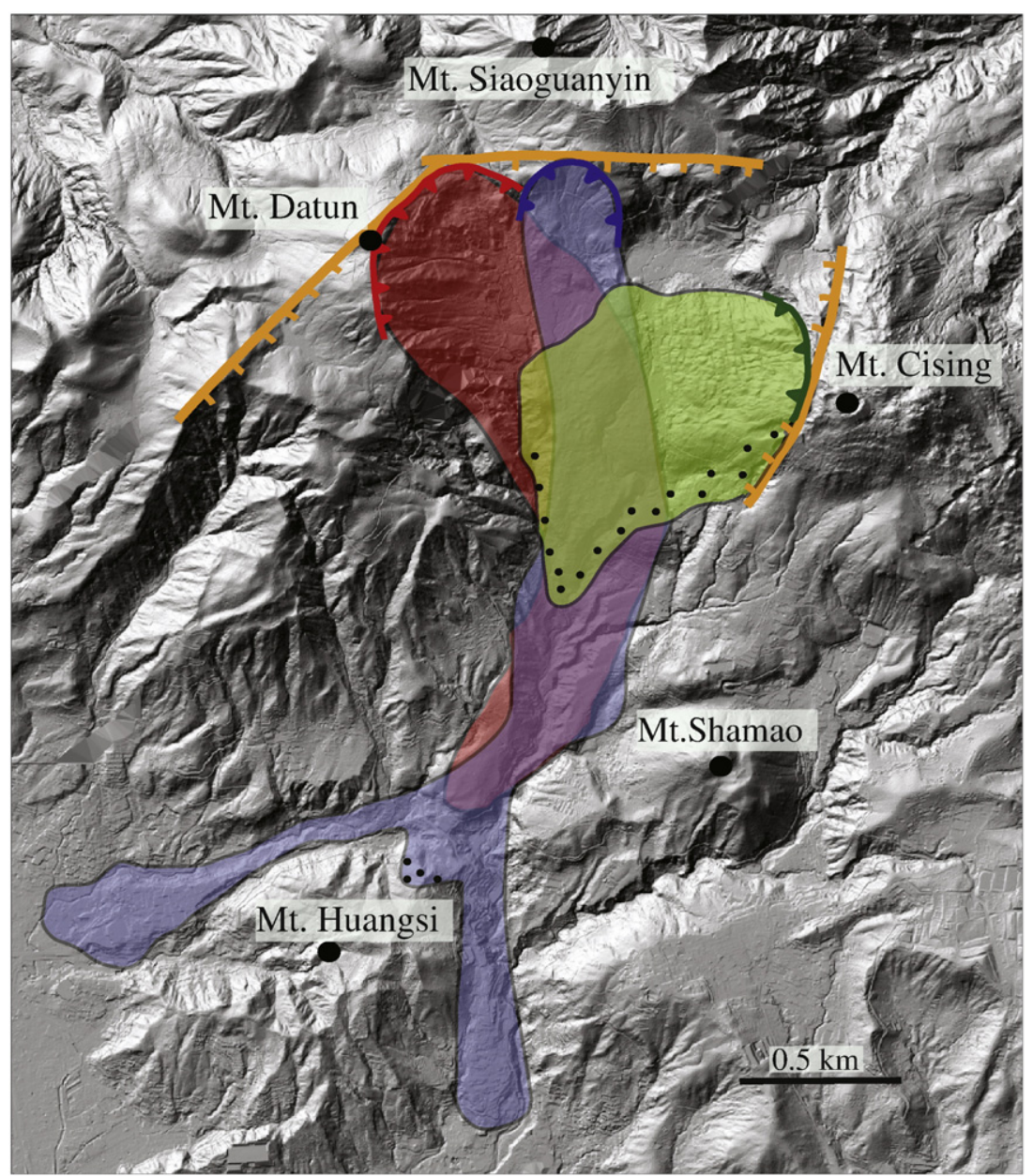

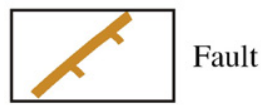

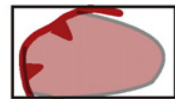

Scar and deposit of Datun avalanche

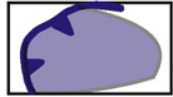

Scar and deposit of

Siaoguanyin avalanche

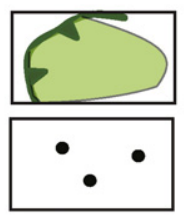

Scar and deposit of

Cising avalanche

Bulldozer facies of

Cising and Siaoguanyin

avalanches

Fig. 7. Distribution of the most recent debris avalanche deposits of TVG superimposed on the DEM-based shadow image (cf. large square in Fig. 1).

distributions of pumice from the tephras of Plinian eruptions of Mt. Cising. Macroscopically and microscopically these pumices are also similar.

Deposits of lithic-rich lahars and pumice-rich lahars contain a very small percentage of clay (Fig. 3c), thus they mobilized little if any material of old, weathered volcanic rocks (which contain a lot of clay),

\section{Table 3}

Characteristics of gravitational collapses of TVG.

\begin{tabular}{|c|c|c|c|c|c|c|}
\hline Name & $\begin{array}{l}\text { Scar } \\
\mathrm{km}\end{array}$ & $\begin{array}{l}\text { Path }(L) \\
\text { km }\end{array}$ & $\begin{array}{l}\text { Height }(H) \\
\mathrm{km}\end{array}$ & $H / L$ & $\begin{array}{l}\text { Volume }(V) \\
\mathrm{km}^{3}\end{array}$ & $\begin{array}{l}\text { Age } \\
\text { years }\end{array}$ \\
\hline Datun & $1 \times 1$ & 5 & 1 & 0.2 & 0.1 & $>24,000 \mathrm{BP}$ \\
\hline Cising & $0.5 \times 0.5$ & 2 & 0.5 & 0.25 & 0.05 & 6010-6080 ВР \\
\hline Siaoguanyin & $0.7 \times 0.7$ & 6 & 1 & 0.16 & 0.02 & $\begin{array}{l}22,660-23,780 \\
\text { BP }\end{array}$ \\
\hline Dajianhou & $0.9 \times 0.9$ & 2 & 0.5 & 0.25 & 0.07 & $?$ \\
\hline Cigu & $0.5 \times 0.5$ & 2 & 0.5 & 0.25 & 0.01 & $?$ \\
\hline
\end{tabular}

but instead redeposited freshly erupted pyroclastic material as well as fragmented material of recent gravitational collapses. Similarly fast redeposition of erupted pyroclasts by lahars was observed after many historical eruptions, for example, from Mount St. Helens and Pinatubo (Janda et al., 1981; Pierson et al., 1996). Thus, age determinations of the lahars may be used for determining approximate eruption ages of pyroclastic material which cannot be dated directly (see Section 7).

\section{Stratigraphy and timing of the most recent volcanic events in the TVG}

The stratigraphy of the youngest volcaniclastic deposits within one of the major drainage systems of TVG was established. The drainage system starts in the broad depression between Datun, Siaoguanin, and Cising volcanoes, from which the narrow deep valley of Siahu Creek emerges (Fig. 1). Going south, the valley takes in multiple small tributaries and becomes broader (as well as changing its name to Dakeng Creek, and then to Nanhuang Creek) and finally enters 


\section{Before collapse.}

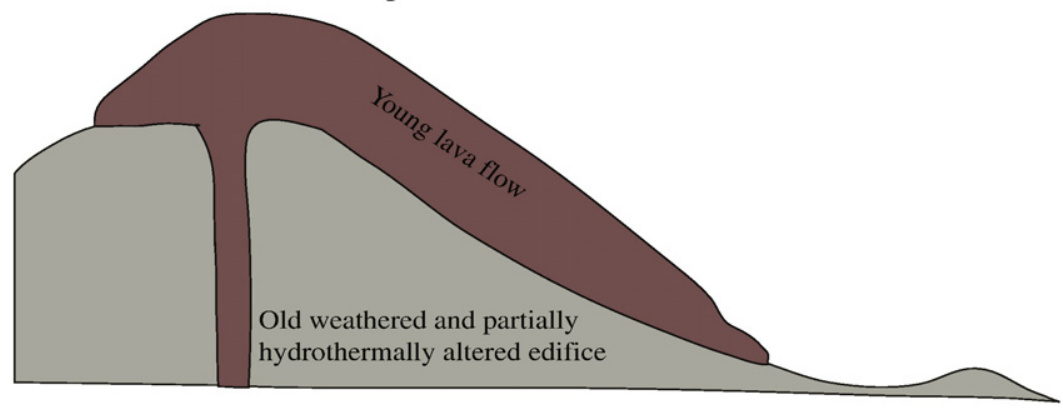

2. Initial stage of collapse

Phreatic decompressioninduced eruption

Secondary detachment surfaces.

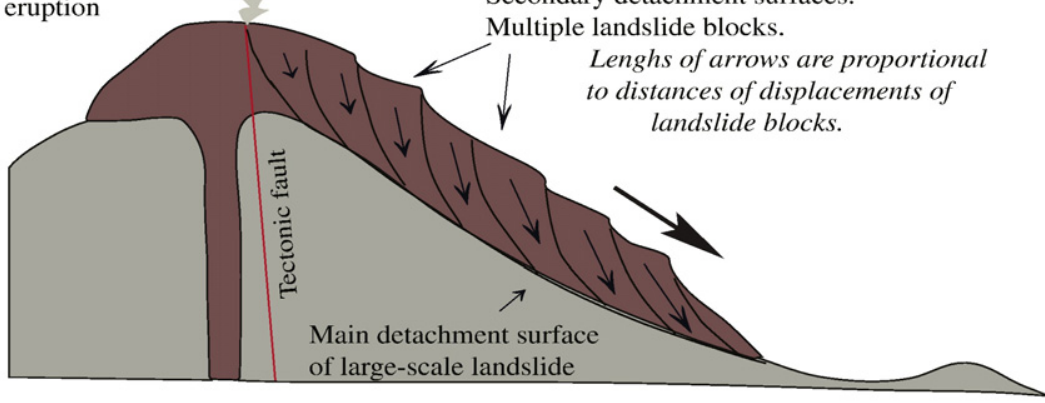

3. Final stage of collapse

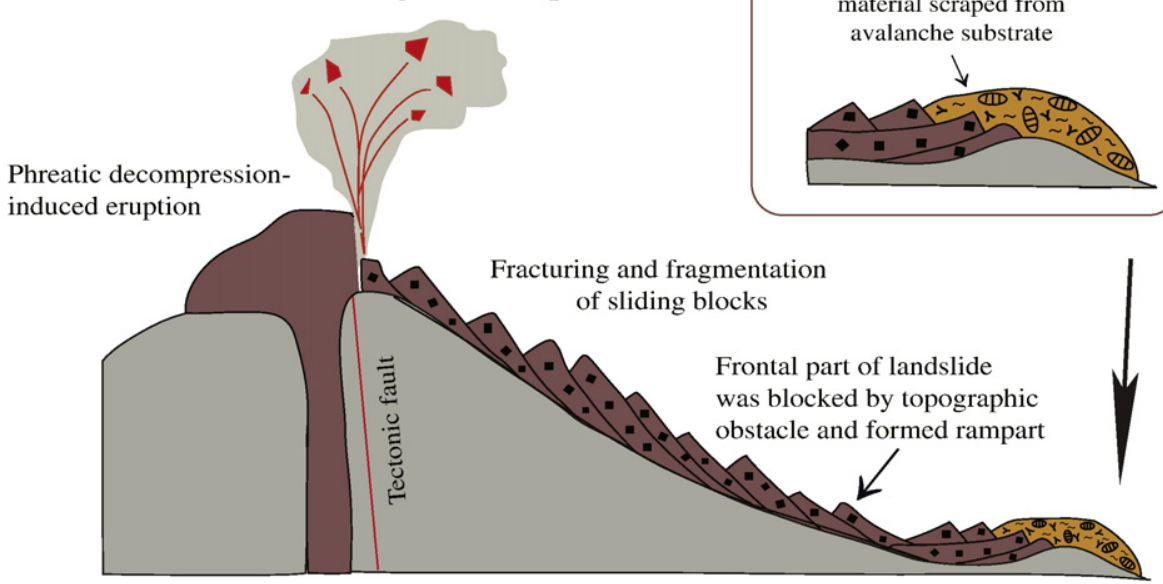

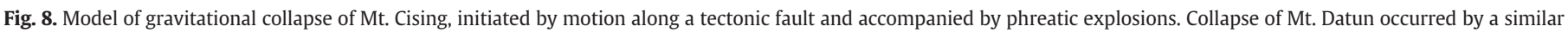
mechanism, but the collapsed material was more mobile, more fragmented, and travelled a larger distance; no phreatic explosions occurred.

northern suburbs of Taipei City. Two stratigraphic columns, formally called Nanhuang Creek stratigraphic column (key location A; Fig. 1) and Huangsinei Creek stratigraphic column (key location B; Fig. 1), were constructed for this area (Fig. 5c). Although direct tracing of deposits between the two columns is impossible due to the lack of outcrops, stratigraphic correlations have been made based on the lithologies of the deposits and five radiocarbon dates (all our samples were dated in Beta Analytic Laboratory, USA).

The Nanhuang Creek stratigraphic column covers a longer period of time. The oldest exposed volcaniclastic deposit in the area is the Datun debris avalanche. No organic material suitable for radiocarbon dating was found in the deposit.

The Datun debris avalanche is directly covered by the deposit of the Siaoguanyin debris avalanche that contains multiple charred fragments of wood dated at 22,660-23,780 BP (here and below 2 Sigma calibrated ${ }^{14} \mathrm{C}$ ages are given; Calibration Database INTCAL04).
The Siaoguanyin debris avalanche is covered by a thick sequence of lahars, which is composed of three units with different lithologies. The lowermost unit is lithic-rich; it resulted from redeposition of the Siaoguanyin debris avalanche material. The middle unit is pumicerich; it resulted from redeposition of pumice fallout deposits of several plinian eruptions of Mt. Cising. The upper unit is lithic-rich; it resulted from redeposition of Merapi-type block-and-ash flows originated from the youngest lava flows of Mt. Cising.

The uppermost unit of the Nanhuang Creek stratigraphic column is the Cising debris avalanche deposit. Fragments of plants from the bulldozer facies of the avalanche deposit were dated at 6010-6080 BP.

The Huangsinei Creek stratigraphic column is complimentary to the Nanhuang Creek stratigraphic column. It spans part of the same period of time, but shows a more detailed record of eruptions because Huangsinei Creek contained a lake in which volcanic ashes were deposited and preserved. 
Two radiocarbon dates were obtained from the lake deposit (Fig. 5). Finely dispersed organic material in the lake sediment taken from the middle of the interval between ash layers 1 and 2 yielded an age of 15,850-16,580 BP; a piece of wood from the lake sediment just below ash layer 4 yielded an age of 13,290-13,640 BP. The lake deposit is covered by a $12-\mathrm{m}$ thick lithic-rich lahar deposit. The lithology of the lahar deposit is similar to lithology of the upper lithicrich lahars of the Nanhuang Creek stratigraphic column. A piece of wood from the lahar deposit resting immediately above ash layer 4 yielded an age of 13,300-13,660 BP.

Deposits of pumice fallouts of Plinian eruptions have not been found intercalated with the paleolake deposits, and thus, no Plinian eruptions occurred in the lake area between approximately 16,000 and $13,000 \mathrm{BP}$. Thus, the lake deposit is probably younger than the pumice-rich lahars of the Nanhuang Creek stratigraphic column.

Stratigraphy and lithologies of the deposits (Fig. 5c) allow us to suggest the following succession of the most recent geological events of the area:

(1) The earliest and largest event in the area was a seismicallytriggered gravitational collapse of Mt. Datun with a volume of $0.1 \mathrm{~km}^{3}$. The resulting debris avalanche completely filled the valley of Siahu-Nanhuang Creek down to Mt. Huangsi. The collapse was followed by some period of time, during which there were no significant depositional events in the main valley; a deep canyon was eroded into the avalanche deposit.

(2) Approximately 23,000 years ago, a flank dome was extruded on the southern slope of Mt. Siaoguanyin. Shortly after its formation (tentatively $<100$ years), part of the still hot dome $\left(0.02 \mathrm{~km}^{3}\right.$ ) collapsed with deposition of a high speed debris avalanche. Soon after deposition, part of the avalanche was extensively reworked, leading to the deposition of multiple lithic-rich lahars.

(3) In the period between 23,000 and 16,000 years ago several Plinian eruptions occurred at Mt. Cising. One of the largest eruptions (VEI 4) formed the Siaoyoukeng tephra ring. Multiple, relatively small lahars, originating at slopes of Mt. Cising, redeposited the erupted pumices.

(4) In the period between 16,000 and 13,000 years ago several small-to-moderate scale vulcanian eruptions occurred in the TVG area (preceding extrusive eruptions of Mt. Cising and possibly Mt. Huangzuei). Thin layers of lithic ashes of the eruptions were deposited in the area and preserved in the lake, which existed at that time near Shamao lava dome.

(5) One of the last magmatic eruptions of Mt. Cising occurred approximately 13,000 years ago. It started with small-to-moderate scale vulcanian explosive activity, which was followed by extrusion of a lava flow; deposits of the accompanying small-scale Merapi-type block-and-ash pyroclastic flows were redeposited by lahars that completely filled the lake near Shamao dome.

(6) Approximately 6000 years ago, possibly as a result of a strong earthquake, a large fissure dissected the summit area of Mt. Cising. This caused small-scale phreatic explosions from several locations along the fissure, as well as provoking gravitational collapse of the western slope of Mt. Cising. The collapsed material produced a debris avalanche of low mobility, with a volume of $0.05 \mathrm{~km}^{3}$. The explosive activity indicates that summit lava flows of Mt. Cising could have been extruded not too long before the opening of the fissure. If so, this may suggest that youngest magmatic eruption of Mt. Cising occurred around 6000 years ago.

\section{Discussion}

\subsection{Timing of the youngest eruptions of the TVG}

$\mathrm{K}-\mathrm{Ar}$ and $\mathrm{Ar}-\mathrm{Ar}$ dating of TVG rocks suggested that these volcanoes stopped erupting more than one hundred thousand years ago (Tsao,
1994). These data are inconsistent with the very good preservation of primary volcanic landforms of several volcanic edifices of the TVG. The climate of the area is humid and subtropical, with precipitation rates of approximately $2000-3000 \mathrm{~mm} /$ year. Under such circumstances, the rates of weathering and erosion of vesicular glass-bearing volcanic rocks are very high. For example, the erosion rate for Central Taiwan was estimated to range between 1 and $10 \mathrm{~mm} /$ year (Dadson et al., 2003). If one was to accept the youngest of the $\mathrm{K}-\mathrm{Ar}$ and $\mathrm{Ar}-\mathrm{Ar}$ ages, together with the slowest possible rate of erosion, at least 100 to 200 meters of the ground surface of these volcanic edifices should have been eroded, eliminating most of the primary features of volcanic relief. Since this is not the case, we suggest that some of the $\mathrm{K}-\mathrm{Ar}$ and $\mathrm{Ar}-\mathrm{Ar}$ ages for the youngest volcanic formations of the TVG are significant overestimates. For example, the youngest lava flows of Cising volcano, which yielded an $\mathrm{Ar}-\mathrm{Ar}$ age of $0.22 \mathrm{Ma}$ (Tsao, 1994), was determined here to have erupted about 13,000 years ago (and possibly as young as 6000 years ago). Finding the reasons for the inaccuracy of some published $\mathrm{Ar}-\mathrm{Ar}$ dates of TVG deposits is beyond the scope of this paper, but we speculate that the youngest of the obtained $\mathrm{Ar}-\mathrm{Ar}$ dates of around $0.2 \mathrm{Ma}$ are close to the lower determination limit of this dating method for the given $\mathrm{K}$ content of TVG rocks. This strongly increases the possibility of significant errors in $\mathrm{Ar}-\mathrm{Ar}$ age determinations if the analyzed rocks were slightly contaminated. Contamination may for example occur through admixing of older xenocrysts from basement rocks to the TVG magmas prior to eruption. Notably, lavas of the TVG are frequently saturated with xenoliths derived from Miocene sandstones. Another possibility is that recharge of a magma chamber with high ${ }^{40} \mathrm{Ar} /{ }^{36} \mathrm{Ar}$ basalt resulted in excess argon in plagioclase (Layer and Gardner, 2001).

Five reliable radiocarbon dates are presented in this contribution for various volcaniclastic deposits of the TVG, and clearly indicate that several magmatic eruptions occurred there in the period between 23,000 and 13,000 years ago. These data are consistent with the stratigraphy of the area, as well as with earlier data of Chen and Lin (2002), which suggested that volcanic ashes originating from the TVG were deposited during the same period of time in Taipei Basin.

Currently, there is no common agreement over what time period of repose is sufficient to consider a volcano as extinct. Although for subduction zone volcanoes, this period was previously believed to be close to about 10,000 years (Szakacs, 1994), several more recent studies have shown that intermediate arc volcanoes commonly display cyclic patterns of intensive eruptive phases followed by relatively long periods of quiescence (thousands to tens of thousands of years), during which there is no evidence for volcanic activity (cf. Zellmer et al., 2003; Zellmer and Clavero, 2006; Sparks et al., 2008). Geophysical and geochemical data have shown that there is a still active magma chamber present below Mt. Cising (Konstantinou et al., 2007). Hence, despite the lack of historic eruptions, from the perspective of volcanic hazard mitigation the TVG volcanoes should be considered as active. There is a high probability of their eruptions in the future.

\subsection{Styles and mechanisms of past and future eruptions of TVG}

It is widely accepted that the past eruptive behavior of a volcano is the key to how it will erupt in the future. The vast majority of volcanic edifices in the TVG are represented by monogenetic lava domes, which were formed by slow extrusion of andesitic, strongly degassed, highly crystalline and very viscous lavas. Individual TVG domes have volumes ranging from 0.05 to $0.3 \mathrm{~km}^{3}$. The data suggest that in the case of a future TVG eruption, the main stage with a high probability will be dome-forming, and the eruption will last several years.

Lava flows of TVG are exceptionally thick and long (Table 2). Calculations based on geometrical characteristics of the flows indicate that these lava flows advanced with average speeds as fast as $6 \mathrm{~m} / \mathrm{h}$ during periods of time lasting as long as 4-5 years. If such a lava flow will form in the course of a future eruption of the TVG, it will pose 
a major hazard. For instance, the Kuosheng nuclear power station is located at a distance only $2 \mathrm{~km}$ from the frontal part of one of the largest lava flows. Only Hunglu volcano in the TVG erupted fluid basaltic lava flows. However, this volcano is one of the youngest, and thus the possibility of a future eruption of more mobile basaltic lava flows cannot be ruled out in the TVG.

Explosive eruptions of the TVG were in most cases mild, and ejected relatively small volumes of pyroclastic material. Based on the characteristics of pyroclastic deposits, the eruptions were very diverse. Vulcanian-type explosions with ejections of dense ballistic blocks and lithic ashes were most common; they were dangerous only in proximal areas ( $<1 \mathrm{~km}$ from the vents). With a high probability the next explosive eruption of TVG will be of vulcanian type. Wet phreatomagmatic eruptions were very rare in TVG (the tuff cone of Mt. Hunglu is the only found example), and also were dangerous only in proximal areas.

Only at Cising volcano we have found deposits of phreatic eruptions. One eruption of this type occurred very recently (about $6000 \mathrm{BP}$ ). Due to their small volumes and limited areal extent, such eruption deposits are easily overlooked, and we suggest that similar eruptions may have occurred at other places of TVG as well. Phreatic explosions commonly happen without precursors in areas with hydrothermal activity. In the TVG, such areas attract a lot of tourists, and thus future phreatic explosions can be very hazardous.

The most vigorous explosive eruptions of the TVG occurred at Cising volcano and were of Plinian type (VEI 4). Such eruptions pose serious hazard not only in proximal areas, but also over distances up to several tens of kilometers downwind. Danger for flying aircraft of such eruptions is well known (Miller and Casadevall, 2000). The long repose period since the last magmatic eruption of Cising suggests that in the case of reactivation, this volcano may once again be the source of highly explosive Plinian activity.

Deposits of pyroclastic density currents have limited distribution in the TVG. Most of them are represented by block-and-ash flows that were formed as a result of small-scale collapses of growing domes and advancing lava flows (Merapi-type pyroclastic flows). These flows travelled only several hundred meters downslope from the source.

Voluminous deposits of ignimbrites, widespread in many volcanic arcs, are completely absent in the TVG. Ignimbrites generally erupt during the formation of large silicic calderas. The lack of ignimbrite deposits raises doubts about the existence of a caldera in the region, which was suggested to explain the deep subsidence of sedimentary bedrocks in the central part of the TVG area (Song et al., 2000b). Subsidence can be more easily linked to purely tectonic reasons (for example to a graben associated with the formation of a pull-apart structure along a major strike-slip fault). Taipei Basin, which is located immediately to the south, experienced similar subsidence without involvement of volcanism (Kim et al., 2005).

Eruptions of the TVG on average were less explosive than eruptions of andesitic island arc volcanoes. This observation cannot be explained by simply assuming that magmas of the TVG at depth had initially a low content of dissolved volatiles. Although we did not measure volatile content in TVG magmas, abundant presence of hornblende in all products of the E-W volcanic ridge clearly indicates that initially (at depth), magmas of the TVG had a significant proportion of dissolved water (at least 3\% according to Eichelberger et al., 1986). Such magmas are potentially very explosive.

The weakly explosive character of TVG volcanism can be explained by syneruptive non-explosive degassing of magma (Eichelberger et al., 1986; Eichelberger, 1995). In the case of the TVG, loss of volatiles probably occurred though country rocks, which were initially extensively fractured by the very active tectonic processes operating in Taiwan. Multiple faults and fractures of various sizes are visible in the basement rocks where they are exposed. A large number of hot and cold springs in the area point to a high permeability of these basement rocks. For the same reason, many explosive eruptions of the
TVG may have been phreatomagmatic: through fractured conduit walls ground water had easy access to the ascending magma.

\subsection{Other hazards related to TVG volcanoes}

Large-scale collapses are common on volcanoes of various types, especially those erupting viscous magmas (Siebert, 1984). In most cases such collapses occur during the course of eruption, when intruding magma disturbs the edifice of the volcano, resulting in loss of gravitational stability (Siebert, 1984; Belousov et al., 1999, 2007). More than 5 scars and debris avalanche deposits formed by gravitational collapses were found in the TVG, indicating that these extremely dangerous events were common in the area. Surprisingly, all of them occurred a long time after the eruptions had ceased. Possible reasons may be the relatively small size of TVG edifices as well as their monogenetic character, so that strong earthquakes and/or motions along tectonic faults in the volcanic basement were necessary to trigger collapses. The mobility of TVG debris avalanches was in the range $0.16-0.25$, which is twice smaller than the average mobility of volcanic debris avalanches (Siebert, 1984). Relatively small volume of TVG collapses $\left(<0.1 \mathrm{~km}^{3}\right)$, the particular type of material involved (lava domes), seismotectonic triggering, or the fact that the collapses occurred long after the volcanoes stopped erupting, or a combination of these factors may have played a role in the low mobility of the resulting debris avalanches. $H / L=0.15$ may be used for hazard mitigation strategies for future collapses within the TVG.

Large-scale gravitational collapses of volcanic edifices of TVG may occur again at any time; an eruption is not necessary to trigger them. For example, currently one of the most unstable slopes is the SSE part of Mt. Datun. It is detached from the main part of the edifice by the Chihshan fault, subsided $\sim 10 \mathrm{~m}$ and dissected by multiple subparallel fissures. For unknown reason this part of the volcano did not collapse previously, when the other part of the slope located to the north collapsed and formed the Datun debris avalanche $>24,000$ years ago. The still standing SSE part of Mt. Datun (with a volume at least $0.03 \mathrm{~km}^{3}$ ) is very steep and has the potential to collapse at any time, especially in the case of a strong tectonic earthquake. Thus, an urgent need exists to estimate the degree of gravitational instability of TVG edifices and to monitor deformations of the most unstable slopes.

During and sometimes after TVG eruptions, as well as after largescale collapses, the formation of lahars of various types and scales was very common. This is due to the very wet climate of Taiwan. It is well known that lahars constitute some of the most lethal volcanic phenomena (e.g., Pierson et al., 1996), thus serious attention should be given to the possibility of lahar formation in the case of future eruptions at the TVG.

\subsection{Location of future eruptions in TVG}

The SW-NE ridge of TVG is composed of old, deeply eroded volcanoes, and future eruptions in that area have a very low probability. The youngest, well-preserved volcanic edifices are evenly scattered along the $\mathrm{E}-\mathrm{W}$ ridge, and thus future eruptions are possible in any area of the ridge. The multivent, monogenetic character of TVG volcanism indicates that future eruptions in the area will not necessarily be connected with reactivation of one of the already existing volcanic edifices. Potentially, magma can reach the ground surface at any part of the E-W ridge. Mt. Cising is probably the youngest volcano, with significant magmatic eruptions at about 13,000 BP (and possibly $6000 \mathrm{BP}$ ). Taking into account that Mt. Cising is the only volcano in the TVG that has the structure of a polygenetic volcano (i.e. it erupted many times through a relatively stable conduit), it is the most probable candidate for reactivation in the future. This notion is supported by the seismic data of Konstantinou et al. (2007) that points to the existence of an active magma chamber under Cising volcano. 


\section{Conclusions}

1. Tatun Volcanic Group is active. Volcanoes of the E-W ridge produced several magmatic eruptions in the period from 23,000 to 13,000 years ago and possibly as recently as 6000 years ago. Mt. Cising is the youngest volcano of the TVG.

2. The last eruptions of the TVG were dominantly extrusive, producing lava domes as well as thick and long lava flows. Eruptions lasted several years, with average discharge rates of magma up to $10 \mathrm{~m}^{3} / \mathrm{s}$.

3. Explosive activity in the TVG was diverse, ranging from weak phreatic to highly explosive Plinian eruptions. Interaction of magma with ground water was common during explosive phases.

4. Tectonically triggered gravitational collapses of volcanic edifices as well as voluminous lahars were common in history of the TVG.

\section{Acknowledgements}

This work has been done when $\mathrm{AB}$ was visiting scholar, and MB was postdoc in the Institute of Earth Sciences, Academia Sinica, Taiwan. We thank Y.-C. Chan for providing DEM-based shadow image of the TVG area, Y. lizuka for his help doing SEM images, K.-L. Wang and S.-R. Song for sharing their experience of the geology of the area, as well as all staff of the IES for their assistance. We thank also S. Cronin and L. Siebert for their helpful comments and suggestions on the manuscript. This work was supported by National Science Council, ROC under grants 097-2116-M-001-007, 097-2811-M-001-056 and 097-2811-M-001-133 to C.H. Chen, and the Institute of Earth Sciences, Academia Sinica, Taipei, Taiwan.

\section{Appendix A. Supplementary data}

Supplementary data associated with this article can be found, in the online version, at doi:10.1016/j.jvolgeores.2010.02.001.

\section{References}

Belousov, A., Belousova, M., 2001. Eruptive process, effects and deposits of the 1996 and ancient basaltic phreatomagmatic eruptions in Karymskoye Lake, Kamchatka, Russia. In: White, J.D., Riggs, N.R. (Eds.), Volcaniclastic Sedimentation in Lacustrine Settings: IAS, 30, pp. 35-60.

Belousov, A., Belousova, M., Voight, B., 1999. Multiple edifice failures, debris avalanches and associated eruptions in the Holocene history of Shiveluch volcano, Kamchatka, Russia. Bulletin of Volcanology 61, 324-342.

Belousov, A., Voight, B., Belousova, M., 2007. Directed blasts and blast-currents: a comparison of the Bezymianny 1956, Mount St Helens 1980, and Soufrière Hills, Montserrat 1997 eruptions and deposits. Bulletin of Volcanology 69, 701-740.

Chen, P.Y., 1965. On the xenoliths of sandstone and shale in andesite from Chihsingshan, Tatun Volcano Group, Taiwan. Procedings of Geological Society of China 8, 91-96.

Chen, C.H., 1970. Geology and geothermal power potential of the Tatun volcanic region. Geothermics 2.

Chen, C.H., 1975. Petrological and chemical study of volcanic rocks from Tatun Volcano Group. Proceedings of Geological Society of China 18, 59-72.

Chen, C.H. (ed). 2000. Geological map of Taiwan, scale 1:50, 000.

Chen, C.H., Wu, Y.J., 1971. Volcanic geology of the Tatun geothermal area, northern Taiwan. Proceedings of Geological Society of China 14, 5-20.

Chen, C.-H., Lin, S.B., 2000. Distribution and significance of volcanic materials in sediments of the Taipei Basin. Journal of Geological Society of China 43, 287-310.

Chen, C.H., Lin, S.B., 2002. Eruptions younger than 20 ka of the Tatun Volcano Group as viewed from the sediments of the Sungshan Formation in Taipei Basin. West Pacific Earth Science 2, 191-204.

Chen, W.S., Yang, C.C., Yang, H.C., Liu, J.K., 2003. Volcanic landform and sequences of the Tatun volcanoes. Bulletin of Central Geological Survey 16, 99-123 (in Chinese).

Dadson, S.J., Hovius, N., Chen, H., Dade, W.B., et al., 2003. Links between erosion, runoff variability and seismicity in the Taiwan orogen. Nature 426, 648-651.

Deguchi, Y., 1912. Report on the geology of the Tatun Volcano Group. Journal of Geological Society of Japan 4, 282-284.

Eichelberger, J.C., 1995. Silicic volcanism: ascent of viscous magmas from crustal reservoirs. Annual Review of Earth and Planetary Sciences 23, 41-63.

Eichelberger, J.C., Carrigan, C.R., Westrich, H.R., Price, R.H., 1986. Non-explosive silicic volcanism. Nature 323, 598-602.

Fink, J.H., Griffiths, R.W., 1998. Morphology, eruption rates, and rheology of lava domes: insights from laboratory models. Journal of Geophysical Research 103 (B1), 527-545.

Fuh, T.M., 1968. Sedimentary xenoliths from andesite in the vicinity of Chutzushan, Tatun Volcano Group, Taiwan. Acta Geological Taiwanica 9, 19-38.
Glicken, H., 1998. Rockslide-debris avalanche of May 18, 1980, Mount St. Helens volcano, Washington. Bulletin of Geological Society of Japan 49, 55-106.

Heiken, G., Wohletz, K., 1985. Volcanic Ash. University of California Press, p. 246.

Ho, C.S., 1986. A synthesis of the geologic evolution of Taiwan. Tectonophysics 125, 1-16.

Houghton, B.F., Wilson, C.J.N., 1989. A vesicularity index for pyroclastic deposits. Bulletin of Volcanology 51, 451-462.

Hsu, Y.J., Yu, S.B., Simons, M., Kuo, L.C., Chen, H.Y., 2009. Interseismic crustal deformations in the Taiwan plate boundary zone revealed by GPS observations, seismicity and earthquake focal mechanisms. Tectonophysics 479, 4-18.

Janda, R.J., Scott, K.M., Nolan, K.M., Martinson, H.A., 1981. Lahar movement, effects, and deposits. In: Lipman, P.W., Mullineaux, D.R. (Eds.), The 1980 Eruptions of Mount St. Helens, Washington: US Geol. Survey, Professional Paper 1981, 1250, pp. 461-478.

Juang, W.S., Chen, J.C., 1989. Geochronology and geochemistry of volcanic rocks in northern Taiwan. Bulletin Central Geological Survey 5, 31-66 (in Chinese).

Kilburn, C., Lopez, R., 1991. General patterns of flow field growth: aa and blocky lavas. Journal of Geophysical Research 96, 19721-19732.

Kim, K.H., Chang, C.H., Ma, K.F., Chiu, J.M., Chen, K.C., 2005. Modern seismic observations in the Tatun volcano region of Northern Taiwan: seismic/volcanic hazard adjacent to the Taipei Metropolitan area. TAO 16, 579-594.

Komorowski, J.-C., Glicken, H., Sheridan, M., 1991. Secondary electron imagery of microcracks and hackly fracture surfaces in sand-size clasts from the 1980 Mount St. Helens debris-avalanche deposit: implications for particle-particle interactions. Geology 19, 261-264.

Konstantinou, K., Lin, C.-H., Liang, W.-T., 2007. Seismicity characteristics of a potentially active Quaternary volcano: the Tatun Volcano Group, Northern Taiwan. Journal of Volcanology and Geothermal Research 160, 300-318.

Layer, P.W., Gardner, J.E., 2001. Excess argon in Mount St. Helens plagioclase as a recorder of magmatic processes. Geophysical Research Letters 28, 4279-4282.

Lee, H.F., Yang, T.F., Lan, T.F., Song, S.R., Tsao, S., 2005. Fumarolic gas composition of the Tatun Volcano Group, Northern Taiwan. TAO 16, 843-864.

Lee, H.F., Yang, T.F., Lan, T.F., Chen, C.H., Song, S.R., Tsao, S., 2008. Temporal variations of gas compositions of fumaroles in the Tatun Volcano Group, northern Taiwan. Journal of Volcanology and Geothermal Research 178, 624-635.

Lin, C.H., Konstantinou, K.I., Liang, W.T., et al., 2005. Preliminary analysis of volcanoseismic signals recorded at the Tatun Volcano Group, northern Taiwan. Geophysical Research Letters 32, L10313.

Liu, J.K., Chan, Y.C., Shih, T.Y., Hsieh, Y.C., 2007. Lidar DEM for characterizing the volcanic landforms of Tatun volcanoes in metropolitan Taipei. IGARSS 2007, 3752-375.

Lo, H.H., 1982. Compositions of Tatun andesites, northern Taiwan. Journal of Volcanology and Geothermal Research 13, 173-187.

Lyman, A.W., Koenig, E., Fink, J.H., 2004. Predicting yield strengths and effusion rates of lava domes from morphology and underlying topography. Journal of Volcanology and Geothermal Research 129, 125-138.

MacKay, M.E., Rowland, S.K., Mouginis-Mark, P.J., Garbeil, H., 1998. Thick lava flows of Karisimbi Volcano, Rwanda: insights from SIR-C interferometric topography. Bulletin of Volcanology 60, 239-251.

Miller, T.P., Casadevall, T.J., 2000. Volcanic ash hazards to aviation. In: Sigurdsson, H. (Ed.) Encyclopedia of Volcanoes. Academic Press, San Diego, California, USA, pp. 915-930.

Moore, H.J., Arthur, D.W.G., Schaber, G.G., 1978. Yield strengths of flows on the Earth, Mars, and Moon. Lunar and Planetary Science Conference Proceedings 3, 3351-3378.

Morrissey, M., Mastin, L., 2000. Vulcanian eruptions. Encyclopedia of Volcanoes. Academic Press, pp. 463-475.

MRSO, 1969. The Geothermal Exploration of Tatun Volcano Group. Report, v.90.

Newhall, C., Self, S., 1982. The volcanic explosivity index (VEI): an estimate of explosive magnitude for historical volcanism. Journal of Geophysical Research 87, 1231-1238.

Oshima, S., 1907. Report on the geology of the Tatun Volcano Group. Journal of Geological Society of Japan 1, 28-43.

Pierson, T.C., Daag, A.S., Delos Reyes, P.J., Regalado, M., 1996. Flow and deposition of posteruption hot lahars on the east side of Mount Pinatubo, July-October 1991. In: Newhall C.G., Punongbayan R.S. (eds) Fire and mud: Eruptions and lahars from Mount Pinatubo, Philippines. Philippine Institute of Volcanology and Seismology, Quezon City and University of Washington Press, 921-950.

Pyle, D., 1989. The thickness, volume and grainsize of tephra fall deposits. Bulletin of Volcanology 51, 1-15.

Siebert, L., 1984. Large volcanic debris avalanches: characteristics of source areas, deposits, and associated eruptions. Journal of volcanology and geothermal research 22, 163-197.

Song, S.R., Yang, T.F., Yeh, Y.H., Tsao, S.J., Lo, H.J., 2000a. The Tatun Volcano Group is active or extinct? Journal of Geological Society of China 43, 521-534.

Song, S.R., Tsao, S.J., Lo, H.J., 2000b. Characteristics of the Tatun Volcanic Eruptions, North Taiwan: implications for a Cauldron Formation and Volcanic evolution. Journal of Geological Society of China 43, 361-378.

Song, S.R., Chen, T.M., Tsao, S., Chen, H.F., Liu, H.C., 2007. Lahars in and around the Taipe basin: implications for the activity of the Shanchiao fault. Journal of Asian Earth Sciences 31, 277-286.

Sparks, R.S.J., Folkes, C.B., Humphreys, M.C.S., Barfod, D.N., Clavero, M., et al., 2008 Uturuncu Volcano, Bolivia: volcanic unrest due to mid-crustal magma intrusion. American Journal of Science 308, 727-769.

Stevenson, R.J., Hodder, A.P., Briggs, R.M., 1994. Rheological estimates of rhyolite lava flows from the Okataina Volcanic Centre, New Zealand. New Zealand Journal of Geology and Geophysics 37, 211-221.

Szakacs, A., 1994. Redefining active volcanoes a discussion. Bulletin of Volcanology 5, 321-325.

Teng, T.S., 1996. Extensional collapse of the northern Taiwan mountain belt. Geology 24, 949-952. 
Tsao, S., 1994. K-Ar age determination of volcanic rocks from the Tatun Volcano Group. Bulletin of Central Geological Survey 9, 137-154 (in Chinese).

Vallance, J.W., Schneider, D.J., Schilling, S.P., 2008. Growth of the 2004-2006 lava dome complex at Mount St. Helens, Washington. In: Sherrod, D.R., Scott, W.E., Stauffer, W.H (Eds.), A Volcano Rekindled; the Renewed Eruption of Mount St. Helens: US Geological Survey Professional Paper, 1750, pp. 169-208.

Venzke, E., Wunderman, R.W., et al. (Eds.), 2009. Global Volcanism, 1968 to the Present: Smithsonian Institution, Global Volcanism Program Digital Information Series, GVP-4.

Walker, G.P.L., 1971. Grain-size characteristics of pyroclastic deposits. Journal of Geology 79, 696-714.

Walker, G.P.L., 1973. Lengths of lava flows. Philosophy Transactions Royal Society of London A 274, 107-118.

Walker, G.P.L., 1981. Plinian eruptions and their products. Bulletin of Volcanology 44 223-240.

Wang, W.S., Chen, C.-H., 1990. The volcanology and fission track age dating of pyroclastic deposits in Tatun Volcano Group, northern Taiwan. Acta Geological Taiwan. 28, 1-30.

Wang, K.L., Chung, S.L., Chen, C.H., et al., 1999. Post-collisional magmatism around northern Taiwan and its relation with opening of the Okinawa Trough. Tectonophysics 308, 363-376.

Wang, K.L., Chung, S.L., O'Reilly, S.Y., Sun, S.S., Shinjo, R., Chen, C.H., 2004. Geochemica constraints for the genesis of post-collisional magmatism and the geodynamic evolution of the northern Taiwan. Journal of Petrology 45, 975-1011.
Witt, M.L.I., Fischer, T.P., Pyle, D.M., Yang, T.F., Zellmer, G.F., 2008. Fumarole compositions and mercury emissions from the Tatun Volcanic Field, Taiwan: results from multicomponent gas analyser, portable mercury spectrometer and direct sampling techniques. Journal of Volcanology and Geothermal Research 178, 636-643.

Wohletz, K.H., Sheridan, M.F., 1983. Hydrovolcanic explosions II. Evolution of basaltic tuff rings and tuff cones. American Journal of Science 283, 385-413.

Yang, T.F., Sano, Y., Song, S.R., 1999. ${ }^{3} \mathrm{He} /{ }^{4} \mathrm{He}$ ratios of fumaroles and bubbling gases of hot springs in Tatun Volcano Group, North Taiwan. Il Nuovo Cimento 22, 281-286.

Yang, C.C., Liu, J.K., Huank, M.T., Chen, W.S., 2004. DTM for mapping the volcanic landforms of Tatun Volcano Group in Northern Taiwan. Journal of Photogrammetry and Remote Sensing 9, 1-8.

Yen, T.P., Tzou, Y.H., Lin, W.H., 1984. Subsurface geology of the Tatun Volcano Group. Petrology and Geology of Taiwan 20, 143-154.

Yu, S.B., Chen, H.Y., Kuo, L.C., 1997. Velocity field of GPS stations in the Taiwan area. Tectonophysics 274, 41-59.

Zellmer, G.F., Clavero, J., 2006. Using trace element correlation patterns to decipher a sanidine crystal growth chronology: an example from Taapaca volcano, Central Andes. Journal of Volcanology and Geothermal Research 156, 291-301.

Zellmer, G.F., Sparks, R.S.J., Hawkesworth, C.J., Wiedenbeck, M., 2003. Magma emplacement and remobilization timescales beneath Montserrat: insights from Sr and Ba zonation in plagioclase phenocrysts. Journal of Petrology 44, 1413-1431.

Zharinov, N., Demyanchuk, Y, 2008. The growth of an extrusive dome on Shiveluch Volcano, Kamchatka in 1980-2007: geodetic observations and video surveys. Volcanology and Seismology 2, 217-227. 